

\section{Sumário}

EDITORIAL

Ingo Wolfgang Sarlet, Lilian Rose Lemos Rocha e Patrícia Perrone Campos Mello

1. Direitos Fundamentais, hermenêutica e meio ambiente

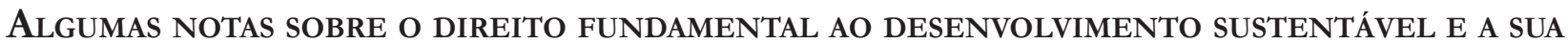
DIMENSÃO SUBJETIVA E OBJETIVA.

Ingo Wolfgang Sarlet e Gabriel de Jesus Tedesco Wedy

El DERECHO HUMANO AL AGUA Y AL SANEAMIENTO.

Belén Burgos Garrido

Até onde VAi o DiReito CONSTITUCIONAL Ao MEIO AMBIENTE ECOlOGICAMENTE EQUILIBRADO? UMA ANÁLISE SOBRE O POSICIONAMENTO BRASILEIRO FRENTE AO NOVO CONSTITUCIONALISMO

LATINO-AMERICANO

Mariana Bruck de Moraes Ponna Schiavetti e Maria Eugênia Bruck de Moraes

El DERECHO HUMANO AL ACCESO A LA INFORMACIÓN AMBIENTAL Y LA JURISPRUDENCIA INTERAMERICANA.

Gonzalo Aguilar Cavallo Garrido

As MÚlTIPLAS DIMENSÕES DO DIREITO FUNDAMENTAL À CIDADE.

Zenildo Bodnar e Priscilla Linhares Albino

Na dúvida EM Favor da natureza? LeVar a sério a Constituição Ecológica na Época do Antropoceno.

Patryck de Araújo Ayala e Mariana Carvalho Victor Coelho

2. Direitos dA NATUREZA................................................................................. 164

A sala de EMERgênCia Ambiental: A PRoteÇão dos direitos da natureza na AmÉrica

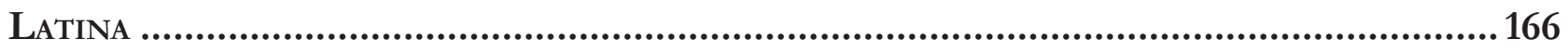

Lilian Rose Lemos Rocha

Procedural theory of THE SubJect of LAW AND NON-HUMan ANimals: CRiteria for RECOGNITION OF LEGAL SUBJECTIVITY FROM THE PERSPECTIVE OF CRITICAL THEORY

Sthéfano Bruno Santos Divino 
Os “ANIMAIS DE PRODUÇÃO” PARA ALIMENTAÇÃO HUMANA E O DIREITO CONSTITUCIONAL AMBIENTAL E ECOLÓGICO: PARADOXOS ÉTICO-JURÍDICOS

Juliane Caravieri Martins e Cicília Araújo Nunes

3. Povos indígenas

Povos Indígenas E PRoteção da NATUREZA: A CAMINHO DE UM “GIRO HERMENÊUTICo ECOCÊNTRICO"

Patrícia Perrone Campos Mello e Juan Jorge Faundes Peñafiel

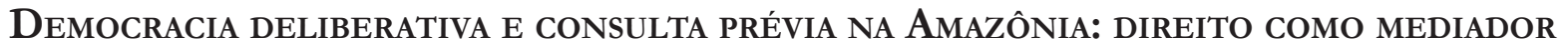

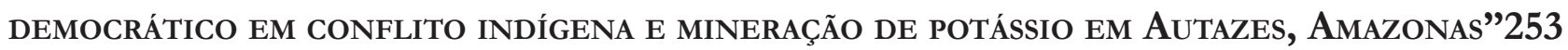
Acursio Ypiranga Benevides Júnior

Rafael da Silva Menezes

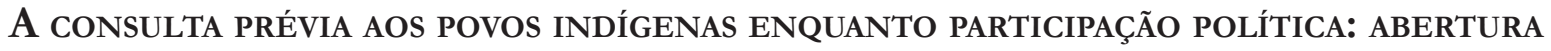
CONSTITUCIONAL BRASILEIRA A ROTAS ALTERNATIVAS DE PROTEÇÃO AMBIENTAL.

Laura Fernanda Melo Nascimento e Adriano Fernandes Ferreira

4. ECOFEMINISMO

MEIO AMbIENTE, CUIDADo E DIREITO: INTERSECÇÕES TEÓRICAS E PRÁTICAS DESDE A DIALÉTICA DA DIFERENÇA 294

Gustavo Seferian e Carol Matias Brasileiro

ECOFEMINISMO INTERSECCIONAL E DECOLONIAL NO DIREITO BRASILEIRO: A NOVA POLÍTICA estadual de SEgurança de barRagens de Minas Gerais.

Émilien Vilas Boas Reis e Vanessa Lemgruber

\section{INSTRUMENTOS E INCENTIVOS PARA A CONCRETIZAÇÃO DA PROTEÇÃO AO MEIO} AMBIENTE

STARTUP E O DESAFIO DO COMPLIANCE

Grace Ladeira Garbaccio, Alexandra Aragão, Vanessa Morato Resende e Ana Walêska Xavier Araújo

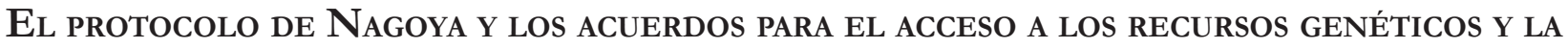
PARTICIPACIÓN JUSTA Y EQUITATIVA EN LOS BENEFICIOS QUE SE DERIVEN DE SU UTILIZACIÓN: UNA PROPUESTA DISCUTIDA

Roberto Concha Machuca

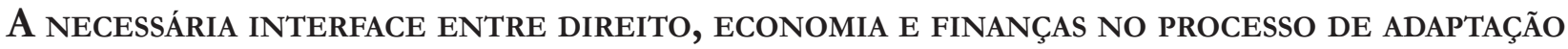
Às MUDANÇAS CLIMÁTICAS 363

Fernanda Dalla Libera Damacena 
RELEVÂNCIA E ESTRATÉGIAS PARA VIABILIZAÇÃo DA CRIAÇÃO DE CORREDORES ECOLÓGICOS EM Área da Mata Atrântica setentrional

Juliana Garcia Vidal Rodrigues, Sueli Aparecida Moreira e Eliza Maria Xavier Freire

AgrotóXICOS, DOMINAÇÃO E FRONTEIRAS: SIGNIFICAÇÃO, RELAÇÃO E PERSPECTIVAS SOBRE O PACOTE TECNOLÓGICO AGRÍCOLA E A AMAZÔNIA BRASILEIRA 418

Giovanni Martins de Araújo Mascarenhas, José Antônio Tietzmann e Silva e Luciane Martins de Araújo

SERÁ O SANEAMENTO BÁSICO UMA ESPÉCIE DE SERVIÇO PÚBLICO DE INTERESSE LOCAL? UM ESTUDO À LUZ DA TEORIA DAS CAPACIDADES ESTATAIS APLICADA AOS MUNICÍPIOS BRASILEIROS.. 440 Thaís de Bessa Gontijo de Oliveira e Fabiana de Menezes Soares

IMPASSES DA ADOÇÃO DA TÉCNICA DE DESSALINIZAÇÃO: BENEFÍCIOS PARA A SAÚDE PÚBLICA E DANOS PARA O MEIO AMBIENTE.

Ivone Rosana Fedel, André Studart Leitão e Gerardo Clésio Maia Arruda

As CONTRATAÇõES PÚBliCAS SUSTENTÁVEIS E A IMPLEMENTAÇão DA META 12.7 DOS OBJETIVOS PARA O DESENVOLVIMENTO SUSTENTÁVEL (ODS) NO BRASIL: AVANÇOS E RETROCESSOS .492 Lucas Campos Jereissati e Álisson José Maia Melo

6. Acesso À justiça em matéria AMbiental.

Desafíos del acceso a la justicia Ambiental en Chile. Jairo Enrique Lucero Pantoja, Gonzalo Aguilar Cavallo e Cristian Contreras Rojas

CONSIDERAÇÕES SOBRE A PARTICIPAÇÃO JUDICIAL DIRETA EM DEFESA DO MEIO AMBIENTE NO Brasil, No Equador e na Bolívia . .556 Leonardo Leite Nascimento e Valmir César Pozzetti

JURISDIÇÃo CONSTITUCIONAL E PATRIMÔNIO CULTURAL: UM ESTUdO DE CASO DA ADPF 206.575 Almir Megali Neto, Flávio Couto Bernardes e Pedro Augusto Costa Gontijo

A TESE DE IMPRESCRITIBILIDADE DE DANOS AMBIENTAIS EM REPERCUSSÃO GERAL DO SUPREMO TRIBUNAL FEDERAL E A POSSIBILIDADE DE APLICAÇÃO DA TEORIA DO RISCO AGRAVADO............602 Vicente de Paulo Augusto de Oliveira Júnior e Daniel Pagliuca

7. Mudanças Climáticas.

Agenda 2030: EMERgênCIA CLIMÁtiCa E O PAPEL DAS INSTITUIÇões PÚBLICAS .624 Luiz Edson Fachin

DÉfis ET PERSPECTIVES POLITIQUES, INSTITUTIONNELles ET NORMATIVES DES AsSEMbléES CITOYENNES: UNE APPROCHE DEPUIS L'EXEMPLE DE LA CONVENTION CITOYENNE SUR LE CLIMAT .636

Benoit Delooz 
Cambio Climático e Inversiones: Esbozando estrategias de armonización para

Andrea Lucas Garí, Jaime Tijmes-Ihl e Johanna Sagner-Tapia

MudANÇAS CLIMÁTICAS E RESPONSABILIDADE CIVIL: UM ESTUDO DE CASO SOBRE A REPARAÇÃo DE

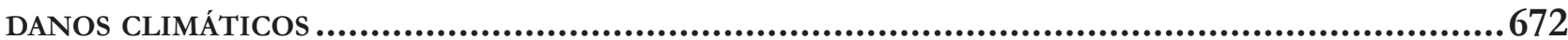

Sabrina Jiukoski da Silva e Thatiane Cristina Fontão Pires 


\title{
Jurisdição constitucional e patrimônio cultural: um estudo de caso da ADPF 206*
}

\author{
Constitutional adjucation and cultural \\ heritage: a case study from ADPF 206
}

\author{
Almir Megali Neto** \\ Flávio Couto Bernardes*** \\ Pedro Augusto Costa Gontijo****
}

* Recebido em $01 / 10 / 2020$

Aprovado em 25/01/2021

** Doutorando, Mestre e Graduado em Direito pela Universidade Federal de Minas Gerais (UFMG). Membro do Centro de Estudos sobre Justiça de Transição (UFMG) e do Grupo de Estudos em Teoria Crítica e Constitucionalismo (UFMG).E-mail: almir_megali@hotmail.com

*** Doutor, Mestre e Bacharel em Direito pela Faculdade de Direito da Universidade Federal de Minas Gerais. Professor do Programa de Pós Graduação da Pontifícia Universidade Católica de Minas Gerais - PUC Minas e da Universidade Federal de Minas Gerais - UFMG. Procurador do Município de Belo Horizonte e advogado.

E-mail: flavio.bernardes@bernardesadvogados. adv.br.

**** Doutorando em Direito Tributário pela Universidade de São Paulo (USP). Bacharel e Mestre em Direito pela Universidade Federal de Minas Gerais (UFMG). Advogado e Parecerista. Professor Substituto de Direito Ambiental do Centro Universitário Newton Paiva. Professor Substituto da PUC-MG. Pesquisador vinculado ao grupo de pesquisa e extensão Observatório para a qualidade da lei - UFMG. E-mail: pedro-acg@hotmail.com.

\section{Resumo}

O presente trabalho é um estudo de caso da decisão monocrática proferida pelo Ministro Edson Fachin na ADPF 206. O objetivo é demonstrar que a extinção da ação sem resolução do mérito pelo Ministro relator do caso partiu de uma compreensão inadequada das espécies de arguição de descumprimento de preceito fundamental previstas pela Lei n. 9.882/99, bem como da técnica da interpretação conforme a Constituição, tendo como resultado a proteção deficiente do meio ambiente histórico-cultural brasileiro. Pretende-se, com isso, explorar as contribuições que a jurisdição constitucional poderia ter dado à proteção do patrimônio cultural brasileiro como desdobramento do direito ambiental cultural. A inovação crítica se dá a partir de método analítico comparativo para verificar qual a melhor técnica de sentença interpretativa, em sede de controle concentrado via ADPF, poderia ser utilizada em questão, bem como o tratamento jurídico do meio ambiente cultural como preceito fundamental da Constituição da República Federativa do Brasil de 1988. A metodologia utilizada é a revisão de literatura, em viés jurídico-interpretativo.

Palavras-chave: ADPF 206. Controle de constitucionalidade. Jurisdição constitucional. Meio ambiente cultural. Patrimônio cultural.

\section{Abstract}

The present work is a case study of the monocratic decision made by Justice Edson Fachin in ADPF 206. Here, the objective is to demonstrate that the decision made by Justice Edson Fachin that extinguished the ADPF 206 without resolution of the merits started from an inadequate understanding of the kinds of allegation of disobedience of a fundamental precept provided for by Law no. 9.882/99 as well of the technique of interpretation according to the Constitution, resulting in a deficient protection of the brazilian historical-cultural environment. The critical innovation of this work is based on a comparative analytical method to verify which is the best interpretative sentence technique of decision-makingcould be used in this case, as well as the legal treatment of the cultural environment as a fundamental precept of the Constitution of Federative Republic of Brazil of 1988. The methodolo- 
gy used is the literature review, in a legal-interpretative bias.

Keywords: APDF 206. Judicial review. Constitutionaladjucation. Environment. Cultural heritage.

\section{Introdução}

A arguição de descumprimento de preceito fundamental (ADPF) é uma das ações especiais do controle concentrado de constitucionalidade brasileiro. Prevista originariamente pelo parágrafo único, do artigo 102, da Constituição de 1988, após a Emenda Constitucional n. 03 de 1993, passou a constar no parágrafo primeiro desse mesmo dispositivo constitucional, conservando, contudo, sua redação original, segundo a qual a referida arguição será apreciada pelo Supremo Tribunal Federal (STF), na forma da lei.

Diante da ausência de precedente de medida judicial semelhante na tradição do controle de constitucionalidade brasileiro, bem como considerando-se o quadro de divergência doutrinária decorrente da aplicação desse instituto oriundo do Direito Comparado, além da própria redação conferida pelo legislador, o STF, já nos primeiros anos de vigência da Constituição de 1988, considerava a medida como autêntica norma de eficácia limitada. Suas regras de processo e julgamento foram regulamentadas somente em 1999, com a promulgação da Lei n. 9.882/1999. Devido à ausência de lei regulamentadora, portanto, por longos onze anos, a arguição ficou carente de aplicação. ${ }^{1}$

Nesse sentido, desde a sua previsão expressa no texto constitucional de 1988, a ADPF é objeto de fortes debates doutrinários e jurisprudenciais que, no mais das vezes, dedicam-se à tarefa de tentar elucidar quais seriam o seu sentido e alcance à luz da Constituição e do sistema de proteção aos direitos fundamentais por ela estabelecido. Durante o processo de elaboração do diploma legal que a regulamentou, essa disputa interpretativa se fez observar nos trabalhos desenvolvidos pela comissão de juristas encarregada de elaborar o projeto, pelo próprio Congresso Nacional e, por fim, pelos vetos apostos pelo Presidente da República à proposição de lei que lhe fora encaminhada para sanção. No entanto, mesmo após a promulgação da lei regulamentadora das suas regras de processo e julgamento, a ADPF continuou a apresentar dificuldades. Segundo Luís Roberto Barroso, "a disciplina lacônica dada pela lei transferiu para o Supremo Tribunal Federal um amplo espaço de conformação do instituto por via de construção jurisprudencial”. ${ }^{2}$

Nesse sentido, observa-se que a ADPF tem como escopo a defesa da estrutura normativa constitucional no que diz respeito ao seu aspecto substancial. Dentre as correntes existentes acerca da forma de identificação de preceitos fundamentais ao longo da Constituição, extravasando o próprio acervo de Direitos Fundamentais, adotar-se-á a que os considera como normas jurídicas materialmente constitucionais. Por essa análise, a proteção ao patrimônio histórico será desenvolvida como preceito fundamental constitucional que aponta para as referências histórico-culturais da sociedade brasileira, ocupando o papel da identidade constitucional coletiva.

Tomados esses pressupostos, o objetivo deste trabalho é justamente explorar os limites e as possibilidades da tese lançada pela decisão monocrática proferida pelo Ministro Edson Fachin para não conhecer e, portanto, para extinguir sem resolução de mérito a ADPF n. 206, à luz dos sistemas de controle de constitucionalidade e de proteção aos direitos fundamentais instituídos pela Constituição de 1988. Proposta pela Procuradoria Geral da República (PGR), a mencionada ação pretendia que, mediante a técnica de interpretação conforme a Constituição, o artigo $1^{\circ}$, do Decreto-Lei n. 25/37, fosse recepcionado pela atual ordem constitucional brasileira para que se adotasse um conceito amplo de patrimônio cultural, incluído no âmbito

STRECK, Lenio Luiz. Jurisdição constitucional. 5. ed. Rio de Janeiro: Forense, 2018, p. 521-525.

2 BARROSO, Luís Roberto. Controle de constitucionalidade no direito brasileiro: exposição sistemática da doutrina e análise crítica da jurisprudência.7. ed. São Paulo: Saraiva, 2016, p. 323. 
da própria proteção jurídica ao meio ambiente. ${ }^{3}$ Nesse sentido, a proteção ao patrimônio cultural, na vertente da proteção ao meio ambiente, nada mais seria do que a proteção de cláusulas materialmente constitucionais, cujo âmbito de proteção se traduz no direito ao ambiente que perfaz a referência histórico-cultural da sociedade brasileira. Os referenciais culturais, na perspectiva do meio ambiente, dão sentido e integridade à própria experiência e condição ontológicas do homem, servindo de substrato para a sua identidade como sujeito e como ser integrante do próprio ambiente que o circunda.

Nesse contexto, o instrumento de tutela de normas constitucionais de natureza fundamental em análise tinha como finalidade a pretensão de que o STF reconhecesse a expansão do conceito de patrimônio cultural a ser protegido pelo poder público e pela coletividade, tendo em vista a mudança de perspectiva de sua tutela conferida pelos artigos 215 e 216 da Constituição de 1988 em relação ao tratamento dado à matéria pelo Decreto-Lei n. 25/37, bem aos moldes daquilo que na doutrina se denomina de "filtragem constitucional". 4 Isto é, a irradiação da eficácia normativa dos preceitos constitucionais aos demais ramos do Direito infraconstitucional, de modo que a estes se aplique leitura compatível com aquele. Objeto que, inevitavelmente, está relacionado à contribuição que a jurisdição constitucional pode dar à problemática da proteção ao patrimônio cultural brasileiro, em sua vertente de verdadeiro desdobramento do direito ambiental cultural.

No desenvolvimento dessa empreitada, o presente trabalho foi dividido em três partes. A primeira dedica-se a recuperar os argumentos lançados pela PGR na inicial da ADPF n. 206, atentando-se para as potencialidades que as sentenças interpretativas, como espécies das sentenças intermediárias que são, ${ }^{5}$ oferecem para a dogmática de proteção aos direitos fundamentais assegurados pela Constituição sem, contudo, abrir mão de suas especificidades. Para isso, será verificado o alcance da proteção ao patrimônio cultural não somente como cláusula constitutiva de preceito fundamental da ordem jurídica constitucional, como também a sua respectiva adequação ao direito ao meio ambiente, em acepção ampla. A segunda parte, por sua vez, avança para um estudo da decisão monocrática proferida pelo Ministro Edson Fachin na ADPF n. 206, evidenciando as razões expostas para a extinção do feito sem resolução de mérito. Na terceira e última parte, serão tecidas considerações críticas ao entendimento exposto pelo citado relator à luz dos sistemas de controle de constitucionalidade e de proteção aos preceitos fundamentais inaugurados e instituídos pela Constituição de 1988. Na conclusão serão apresentadas as considerações finais nas quais, de forma sintetizada, os argumentos desenvolvidos nas seções anteriores serão recuperados a fim de responder ao problema proposto: se haveria inadequação da tese lançada pelo Ministro Edson Fachin para extinguir sem resolução de mérito a ADPF n. 206, especialmente tratando-se de ampliação da proteção constitucional ao meio ambiente histórico-cultural. A metodologia utilizada é a revisão de literatura.

\section{ADPF n. 206 e a proteção ao meio ambiente cultural à luz da Constituição de 1988}

A PGR propôs a ADPF n. 206 perante o STF para que, mediante interpretação conforme a Constituição, aquele Tribunal reconhecesse a expansão do conceito de patrimônio cultural a ser tutelado pelo poder público e pela coletividade. ${ }^{6}$ Em síntese, alegou a requerente que o artigo 216 da atual Constituição da República estabeleceu a referibilidade à identidade, à ação e à memória dos diferentes grupos formadores da sociedade

SILVA, José Afonso da. Direito Ambiental Constitucional. 4. Ed. São Paulo: Malheiros, 2003, p. 20-22.

4 SOUZA NETO, Cláudio Pereira de; SARMENTO, Daniel. Direito constitucional: teoria, história e métodos de trabalho. 2. ed. Belo Horizonte: Fórum, 2016, p. 44.

5 MEYER, Emilio Peluso Neder. Decisão e jurisdição constitucional: crítica às sentenças intermediárias, técnicas e efeitos do controle de constitucionalidade em perspectiva comparada.Rio de Janeiro: Lumen Juris, 2017, p. 17.

6 Conforme se extrai da petição inicial da ação de arguição de descumprimento de preceito fundamental autuada sob o n. 206, protocolizada perante o STF aos 08 de janeiro de 2010 e de lavra da então Procuradora-Geral da República em Exercício, Sandra Cureau, em consulta aos autos eletrônicos realizada aos 10 de setembro de 2020. 
brasileira como critério para reconhecer bem cultural.

Nesse sentido, argumentou que o artigo $1^{\circ}$, do Decreto-Lei n. 25/37, não protegeria adequadamente o patrimônio cultural brasileiro, pois possuiria definição restrita e limitada de bem cultural para fins de sua proteção pela coletividade e pelo Estado. Segundo a PGR, nos termos do dispositivo legal impugnado, bem cultural se referiria, apenas, a aspectos históricos e estéticos que estivessem intimamente relacionados com fatos memoráveis da história do Brasil, ou que tivessem excepcional valor arqueológico, etnográfico, bibliográfico ou artístico ou, ainda, se se tratassem de sítios ou paisagens de feição notável, por obra da natureza ou do homem. Essa definição, em contraposição à normatividade constitucional, restringiria o âmbito de proteção do direito ao meio ambiente cultural, considerando-se que a própria eficácia constitucional é produzida conforme o parâmetro legal do Decreto-Lei n. 25/37 por parte da Administração, no que diz respeito à emanação de seus respectivos atos executórios.

Sustentou, ainda, que, a partir da década de 1980, a ideia de patrimônio cultural passou a estar associada como fator, produto ou imagem de constituição e identidade dos povos, vinculada ao sentido de pertença à multiplicidade de elementos formadores da sociedade humana e à preservação de sua memória. Além disso, segundo a requerente, nesse mesmo período, a proteção ao patrimônio cultural deixou de ser mero dever ou tarefa do Estado para se converter em direito fundamental de dimensão transindividual e difusa. Com isso, a intelecção do dispositivo legal objeto de controle na ADPF n. 206 teria sido ampliada. Esse argumento é amplamente sedimentado na doutrina constitucional brasileira:

a Constituição Federal de 1988 amplia a noção de patrimônio cultural com o reconhecimento, tanto dos bens de natureza material, como os de natureza imaterial portadores de referência à identidade, à ação, à memória dos diferentes grupos formadores da sociedade brasileira. A inclusão dos bens de natureza imaterial no rol de bens culturais merecedores de proteção jurídica, em sede constitucional, significa e desvela um novo momento da historicidade do direito no que diz respeito ao não ocultamento das múltiplas e plurais representações culturais dos povos formadores do tecido social e, consequentemente, da memória brasileira. Classicamente, a proteção jurídica do patrimônio cultural, recaía sobre bens de natureza material. [...] Assim, a atual proteção constitucional do patrimônio cultural configura um rompimento com a exclusividade histórica do paradigma da materialidade, para ampliar e incluir, de modo complexo, os bens culturais de natureza imaterial. ${ }^{7}$

Segundo a PGR, não obstante a transformação conceitual atravessada pela expressão, suas primeiras interpretações não teriam dado conta da ruptura paradigmática do sentido de proteção ao meio ambiente cultural promovida pelos artigos 215 e 216 da atual Constituição da República. Por essa razão, foi requerida a manutenção do artigo $1^{\circ}$, do Decreto-Lei n. 25/37, no ordenamento jurídico pátrio, desde que com interpretação compatível com o texto constitucional. Isto é, a pretensão contida nos autos da ADPF em questão foi no sentido de que houvesse a recepção do dispositivo normativo impugnado a partir de uma interpretação que conferisse unidade semântica ao plexo normativo encarregado da proteção ao patrimônio cultural brasileiro. A unidade de significado, por sua vez, viria a adensar ainda mais a proteção ao meio ambiente cultural humano, que se traduz em uma das grandes vertentes de reconhecimento e de identidade em nossa sociedade.

Toda a argumentação realizada pela PGR se dá no sentido de evitar que, aos dispositivos que serviram como parâmetro de controle, fosse conferida uma espécie de "interpretação retrospectiva", já que os dispositivos constitucionais em referência estariam sendo interpretados à luz do Decreto-Lei n. 25/37, enquanto que o correto deveria ser exatamente o contrário. Assim, não obstante a transformação operada na redação conferida aos artigos que cuidam da proteção ao meio ambiente em sua face de patrimônio cultural brasileiro pela Constituição de 1988, em virtude da redação do texto normativo do Decreto-Lei, havia manifestações, jurisdicionais inclusive, que demonstravam a possibilidade de compreender as novas normas consti-

MOLINARO, Carlos Alberto; DANTAS, Fernando Antonio de Carvalho Dantas. Comentário ao artigo 216. In: CANOTILHO, José Joaquim Gomes; MENDES, Gilmar Ferreira; SARLET, Ingo Wolfgang; STRECK, Lenio Luiz. (Orgs.). Comentários à Constituição do Brasil. São Paulo: Saraiva/Almedina, 2013, p. 4282. 
tucionais de maneira muito semelhante aos preceitos que vigoravam no regime anterior. Isso seria possível, por exemplo, socorrendo-se aos elementos tradicionais de interpretação da hermenêutica constitucional por sua simples interpretação literal.

A amplitude da interpretação constitucional deve se dar conforme a realidade para a qual aponta e para a qual pretende modificar. A partir da utilização de métodos hermenêuticos clássicos, que sequer conseguem dar conta da complexidade dos atuais ordenamentos jurídicos, a apreensão das regras valorativas constitucionais será sempre feita de forma deficitária. A própria noção de meio ambiente cultural, que por tanto tempo foi negligenciada nos escritos jurídicos, sociológicos e arquitetônicos brasileiros, acaba por reconfigurar a forma de perceber o fenômeno do patrimônio cultural, especificamente do patrimônio material, no presente caso, como algo para além da mera identificação de obras ou entes concretos que se referenciem a dado período histórico. O meio ambiente cultural, em certo sentido, é responsável pela formação moral e identitária de todos aqueles que co-participam de sua presença - seja na perspectiva do patrimônio material, seja na perspectiva do patrimônio imaterial -, sendo não somente um elemento de resgate, como também elemento de prospecção daquilo que trazemos como constitutivo da nossa própria história, possibilitando a modelagem do futuro a partir das bases do passado, que reverberam no presente.

Diante desse quadro de utilização anacrônica dos mecanismos interpretativos no sistema de jurisdição constitucional brasileiro, especialmente quando se fala da identificação de preceitos fundamentais, ou de direitos e garantias fundamentais, bem como de sua expansão em nível de densidade semântica, Luís Roberto Barroso defende que

Deve-se rejeitar uma das patologias crônicas da hermenêutica constitucional brasileira, que é a interpretação retrospectiva, pela qual se procura interpretar o texto novo de maneira a que ele não inove nada, mas, ao revés, fique tão parecido quanto possível com o antigo. Com argúcia e espírito, José Carlos Barbosa Moreira estigmatiza a equivocidade dessa postura: "Põe-se ênfase nas semelhanças, corre-se um véu sobre as diferenças e conclui-se que, à luz daquelas, e a despeito destas, a disciplina da matéria, afinal de contas, mudou pouco, se é que na verdade mudou. É um tipo de interpretação... em que o olhar do intérprete se dirige antes ao passado que ao presente, e a imagem que ele capta é menos a representação da realidade que uma sombra fantasmagórica". 8

Ainda segundo Barroso, a interpretação conforme a Constituição pode ser considerada um mecanismo de atuação prática do fenômeno da constitucionalização do Direito. ${ }^{9}$ A expressão constitucionalização do Direito não possui significado unívoco, abarcando, pelo menos, dois fenômenos distintos: a "constitucionalização inclusão" e a "constitucionalização releitura" ${ }^{10}$ A "constitucionalização inclusão" consiste na inserção de matérias tipicamente afetas ao direito infraconstitucional nos textos constitucionais. Exemplares nesse sentido são a Constituição portuguesa de 1976, a Constituição espanhola de 1978 e a própria Constituição brasileira de 1988, que incluem em seus textos normas que extrapolam os assuntos tratados por aquelas normas tradicionalmente tidas como materialmente constitucionais. Por sua vez, a "constitucionalização releitura" diz respeito ao fenômeno pelo qual todo o ordenamento jurídico infraconstitucional passa a ser lido à luz das normas constitucionais, que condicionam o alcance, o sentido, a eficácia e a validade daquele.

É justamente esse sentido da expressão constitucionalização do Direito que é promovido pela interpretação conforme a Constituição e é objeto do pedido da PGR no âmbito da ADPF n. 206. Quando "se fala em constitucionalização do direito, a ideia mestra é a irradiação dos efeitos das normas (ou valores) constitucionais aos outros ramos do direito". ${ }^{11}$ Barroso também empresta à expressão esse mesmo sentido ao pre-

\footnotetext{
BARROSO, Luís Roberto. Interpretação e aplicação da Constituição: fundamentos de uma dogmática constitucional transformadora. 7. ed. 3. Tiragem. São Paulo: Saraiva, 2014, p. 75.

9 BARROSO, Luís Roberto. Curso de direito constitucional contemporâneo: os conceitos fundamentais e a construção do novo modelo. 5. ed. São Paulo: Saraiva, 2015, p. 403.

10 SOUZA NETO, Cláudio Pereira de; SARMENTO, Daniel. Direito constitucional: teoria, história e métodos de trabalho. 2. ed. Belo Horizonte: Fórum, 2016, p. 44.

11 SILVA, Virgílio Afonso da. A constitucionalização do direito: os direitos fundamentais nas relações entre particulares. São Paulo: Malheiros
} 
conizar que "a ideia de constitucionalização do Direito aqui explorada está associada a um efeito expansivo das normas constitucionais, cujo conteúdo material e axiológico se irradia, com força normativa, por todo o sistema jurídico". ${ }^{12}$ Souza Neto e Sarmento denominam o fenômeno de constitucionalização releitura. Para referidos autores, "trata-se de uma consequência da propensão dos princípios constitucionais de projetarem uma eficácia irradiante, passando a nortear a interpretação da totalidade da ordem jurídica”. Com isso, afirmam que "os preceitos legais, os conceitos e institutos dos mais variados ramos do ordenamento, submetem-se a uma filtragem constitucional: passam a ser lidos a partir da ótica constitucional". ${ }^{13}$ Meyer, por sua vez, considerando a eficácia irradiante dos direitos fundamentais sobre o restante do ordenamento jurídico, afirma que os "direitos fundamentais dariam a estrutura básica do Estado Democrático de Direito. Esse movimento é o que permitiria falar em uma 'constitucionalização' do Direito”. ${ }^{14}$

Assim, as normas constitucionais condicionariam a interpretação do Direito infraconstitucional ao passo que vinculariam os poderes estatais, exigindo destes a observância de seus preceitos. ${ }^{15} \mathrm{Com}$ isso, consagrou-se a supremacia, bem como a força normativa da Constituição. ${ }^{16}$ Logo, pode-se dizer que, em toda interpretação jurídica, haverá interpretação constitucional e que a aplicação do direito necessariamente envolverá, direta ou indiretamente, a aplicação da Constituição. Será direta na hipótese em que a pretensão deduzida em juízo e o provimento jurisdicional estiverem fundados em algum enunciado normativo extraído diretamente do texto constitucional. A Constituição será indiretamente aplicada quando se tratar de verificar a compatibilidade da norma infraconstitucional, seja ela pré-constitucional ou pós-constitucional, com a Constituição e de orientar a interpretação do direito ordinário à satisfação das diretrizes constitucionais. Ao final da leitura do sistema jurídico, todas as normas devem ser ajustadas ao programa normativo constitucional, que tem como função estabelecer o núcleo mínimo de valores normativos que servirão de parâmetro para a interpretação do sistema jurídico.

Consoante Virgílio Afonso da Silva, "essa irradiação é um processo e, como tal, pode se revestir de diversas formas e pode ser levada a cabo por diferentes atores". ${ }^{17}$ Assim, com relação ao Legislativo e ao Executivo, a constitucionalização do Direito restringe o espectro de discricionariedade e de liberdade de conformação destes na elaboração das leis em geral, impõem-lhes o dever de atuar em prol da realização dos direitos assegurados pela Constituição e, especificamente no caso do Executivo, fornece fundamento para

Editores, 2005, p. 38 .

12 BARROSO, Luís Roberto. Curso de direito constitucional contemporâneo: os conceitos fundamentais e a construção do novo modelo. 5. ed. São Paulo: Saraiva, 2015,p. 391.

13 SOUZA NETO, Cláudio Pereira de; SARMENTO, Daniel. Direito constitucional: teoria, história e métodos de trabalho. 2. ed. Belo Horizonte: Fórum, 2016, p. 44.

14 MEYER, Emilio Peluso Neder.Uma teoria dos direitos fundamentais a partir da Constituição de 1988: as principais contribuições para a construção de uma metódica brasileira. In: CLÈVE, Clemèrson Merlin; FREIRE, Alexandre (Orgs.). Direitos Fundamentais e Jurisdição Constitucional.São Paulo: RT, 2014, v. 1, p. 370.

15 Não se desconhece que a aplicação de uma dimensão objetiva dos direitos fundamentais pela jurisprudência do Tribunal Constitucional Federal Alemão, que ao julgar o Lüth, em 1958, deu origem ao fenômeno da constitucionalização do Direito, implicou a chamada jurisprudência de valores, segundo a qual os direitos plasmados na Constituição refletiriam os valores supostamente compartilhados por toda a sociedade, cabendo ao Judiciário proteger e promover tais valores no exercício de suas funções. Tampouco se desconhece as críticas que têm sido formuladas a essa compreensão, especialmente no que se refere à atribuição à jurisdição constitucional da prerrogativa de ditar à sociedade os padrões de comportamento ética ou pragmaticamente desejáveis. No entanto, por extrapolar o objeto de estudo deste trabalho, tais questões não serão abordadas aqui. Para uma leitura neste sentido, vejam-se: CATTONI DE OLIVEIRA, Marcelo Andrade. Devido processo legislativo: uma justificação democrática do controle jurisdicional de constitucionalidade das leis e do processo legislativo. 3. ed. rev. ampl. e atual. Belo Horizonte: Fórum, 2016a, p. 77-103; CATTONI DE OLIVEIRA, Marcelo Andrade de. Processo constitucional. 3. ed. Belo Horizonte: Fórum, 2016b, p. 127-139; CRUZ, Álvaro Ricardo de Souza. Jurisdicão constitucional democrática. 2. ed. Belo Horizonte: Arraes Editores, 2014, p. 200-277; MEYER, Emilio Peluso Neder. A decisão no controle de constitucionalidade. São Paulo: Método, 2008, p. 355-412; e MEYER, Emilio Peluso Neder. Decisão e jurisdição constitucional: crítica às sentenças intermediárias, técnicas e efeitos do controle de constitucionalidade em perspectiva comparada.Rio de Janeiro: Lumen Juris, 2017, p. 219-268.

16 HESSE, Konrad. A força normativa da constituição. Tradução de: Gilmar Ferreira Mendes. Porto Alegre: Sergio Antônio Fabris, 1991, p. 18-20.

17 SILVA, Virgílio Afonso da. A constitucionalização do direito: os direitos fundamentais nas relações entre particulares. São Paulo: Malheiros Editores, 2005, p. 38. 
aplicação imediata da Constituição, sem que para isso seja necessária elaboração de leis pelo legislador. Com relação ao Judiciário, serve de parâmetro para o controle de constitucionalidade das leis e de vetor interpretativo do direito infraconstitucional. A existência de um bloco de constitucionalidade específico à proteção ambiental, orientada para o meio ambiente cultural, aplicável ao âmbito da proteção ao patrimônio histórico, artístico e cultural, material ou imaterial, eleva a hermenêutica constitucional ao patamar de conformação máxima. Para isso, os instrumentos processuais contidos no sistema pátrio devem servir, singularmente, à sua finalidade integradora e mediadora: serem meios para a concretização da Constituição através da "vontade de Constituição", tomando-se a clássica expressão de Hesse. ${ }^{18}$

Além da parcela da doutrina crítica a uma possível "jurisprudência dos valores" que poderia ser viabilizada pela constitucionalização do Direito, desde que os direitos fundamentais sejam compreendidos em sua dimensão objetiva, há quem também aponte os riscos de uma constitucionalização excessiva para o próprio funcionamento do regime democrático. Aqui, o alerta é no sentido de que uma constitucionalização do Direito não deveria restringir a liberdade de conformação do legislador no seu legítimo exercício de concretização da Constituição, a não ser naqueles casos em que houver incompatibilidade entre o direito infraconstitucional e a Constituição. Por isso, a interpretação constitucional feita pelo Poder Judiciário não pode ser tão ampla a ponto de impedir que principalmente o Legislativo também interprete e delibere sobre o sentido da Constituição. ${ }^{19}$

A interpretação conforme a Constituição, no contexto de avaliação da ADPF n. 206, pode ser considerada mecanismo de atuação prática do fenômeno da constitucionalização do Direito, na medida em que é uma técnica de decisão do controle jurisdicional de constitucionalidade das leis que visa delimitar determinado texto legal infraconstitucional na sua aplicação, atribuindo-lhe conteúdo compatível com o texto constitucional. Sendo assim, por meio dessa técnica de hermenêutica constitucional, o órgão judicial, no exercício do controle de constitucionalidade das leis, deverá atribuir ao ato normativo objeto de controle um sentido que seja adequado à Constituição, evitando, dessa maneira, que este seja extirpado do ordenamento jurídico. ${ }^{20}$

Como se viu, a PGR pretendia que ao artigo $1^{\circ}$, do Decreto-Lei n. 25/37, fosse conferida interpretação consentânea à ruptura paradigmática promovida pela Constituição de 1988 em relação à proteção ao patrimônio ambiental cultural, em especial por uma leitura conjunta dos seus artigos 215 e 216 . Não almejava a declaração da total incompatibilidade do dispositivo normativo objeto de controle, mas apenas e tão somente que a ele fosse conferida uma interpretação harmônica e adequada ao conteúdo semântico da Constituição por meio da técnica da interpretação conforme, para que assim o mesmo fosse recepcionado pela atual ordem constitucional brasileira. ${ }^{21}$

Trata-se o caso, então, de averiguar a adequação da aplicação do controle de constitucionalidade abstrato, no fenômeno de recepção, em relação ao direito "pré-constitucional", de forma a realizar a técnica de interpretação conforme a Constituição para a proteção do núcleo fundamental do direito ao meio ambiente cultural contido nos artigos 215 e 216 da Constituição de 1988. A possibilidade de controle concentrado de constitucionalidade de norma pré-constitucional é bastante densa e controvertida, suscitando divergências doutrinárias e jurisprudenciais.

\footnotetext{
18 HESSE, Konrad. A força normativa da constituição. Tradução de: Gilmar Ferreira Mendes. Porto Alegre: Sergio Antônio Fabris, 1991, p. 17.

19 Nesse sentido, vejam-se: BARROSO, Luís Roberto. Curso de direito constitucional contemporâneo: os conceitos fundamentais e a construção do novo modelo. 5. ed. São Paulo: Saraiva, 2015, p. 430-433; SARMENTO, Daniel. Ubiqüidade constitucional: os dois lados da moeda. In: SARMENTO, Daniel; SOUZA NETO, Cláudio Pereira de (Orgs.). A constitucionalização do direito: fundamentos teóricos e aplicações específicas. Rio de Janeiro: Lumen Juris, 2007, p. 113-148.

20 Sobre a interpretação conforme a Constituição, Cf. MEYER, Emilio Peluso Neder. Decisão e jurisdição constitucional: crítica às sentenças intermediárias, técnicas e efeitos do controle de constitucionalidade em perspectiva comparada. Rio de Janeiro: Lumen Juris, 2017, p. 21-44. 21 Diz-se recepcionado porque, conforme a tradicional jurisprudência do STF, o direito pré-constitucional incompatível materialmente com a nova Constituição, acaso existente, é por esta revogado. A incompatibilidade há de ser vislumbrada apenas do ponto de vista material, pois a forma é regida pela lei da época do ato sendo irrelevante, portanto, para fins do juízo de recepção, conforme o antigo brocardo jurídico tempus regitactum. Cf. BRASIL. Supremo Tribunal Federal. ADI 2. Rel. Min. Paulo Brossard. Julgamento em: 06/02/1992. DJ: 21/11/1997.
} 
Ao abordar a função da jurisdição constitucional nessa hipótese, Gilmar Mendes afirma que "o Supremo Tribunal Federal admitiu, inicialmente, a possibilidade de examinar, no processo do controle abstrato de normas, a questão da derrogação do direito pré-constitucional em virtude de colisão entre a Constituição superveniente e o direito pré-constitucional". ${ }^{22}$ No caso, explica o constitucionalista que o STF julgava a representação de inconstitucionalidade improcedente, contudo, reconhecia-se a colisão entre a norma pré-constitucional e a Constituição vigente a partir do exame de preliminar suscitada, que seria decidida no processo de controle abstrato de normas.

A evolução da jurisprudência do STF se deu no sentido de afastar essa possibilidade de avaliação de normas pré-constitucional, de maneira a invocar o princípio geral de direito intertemporal: lex posterior derogat priori, a partir de exame incidental, no que hoje é conhecido como controle difuso, exercido por toda a jurisdição estatal, como defendido pelo Ministro Moreira Alves, quando do julgamento da Representação n. 1.012. ${ }^{23}$ Já com a plena vigência e eficácia da Constituição de 1988, a discussão foi assentada no âmbito da já referida ADI n. 2. Nessa oportunidade, como narra Gilmar Mendes, o então Ministro Relator Paulo Brossard e o Ministro Sepúlveda Pertence foram os realizadores das teses antagônicas acerca da possibilidade de controle de constitucionalidade em abstrato, ou não, das normas pré-constitucionais.

O Ministro Paulo Brossard, relator da ADI n. 2, conduziu sua argumentação a partir da eficácia constitucional no que diz respeito à conferência de competência específica para os órgãos legislativos atuarem, de forma que as normas produzidas de acordo com as regras da Constituição vigente somente são realizáveis porque há um corpo legislativo por ela criado e, ao mesmo tempo, a partir das regras de processo legislativo constitucional. Dessa maneira, o Poder Legislativo não estaria em qualquer medida vinculado às Constituições anteriores, devendo obediência, tão somente, à Constituição atual. Finalizou seu raciocínio com a seguinte conclusão:

é por esta singelíssima razão que as leis anteriores à Constituição não podem ser inconstitucionais em relação a ela, que veio a ter existência mais tarde. Se entre ambas houver inconciliabilidade, ocorrerá revogação, dado que, por outro princípio elementar, a lei posterior revoga a lei anterior com ela incompatível e a lei constitucional, como lei que é, revoga as leis anteriores que se lhe oponham. ${ }^{24}$

Por outro lado, a divergência foi aberta pelo Ministro Sepúlveda Pertence, que defendeu que, a partir do princípio da supremacia da Constituição, também a lei pré-constitucional deveria ser objeto de controle. É da essência do controle de constitucionalidade que ele seja feito a partir da própria estrutura do ordenamento jurídico. O fato de a lei ser pré-constitucional ou pós-constitucional não faz com que haja uma cisão dos ordenamentos, pelo contrário. Pelo princípio da unidade da ordem constitucional, qualquer norma poderia ser contraposta ao respectivo parâmetro constitucional e, por conseguinte, submeter-se à verificação de adequação. A argumentação do Ministro é clara:

a inconstitucionalidade é apenas o resultado de um juízo de compatibilidade entre duas normas, ao qual é de todo alheia a qualquer ideia de culpabilidade ou responsabilidade do autor da norma questionada pela ilicitude constitucional.

A razão, por isso, cabe a Jorge Miranda (Manual, cit., II/250), quando anota que 'a inconstitucionalidade não é primitiva ou subsequente, originária ou derivada, inicial ou ulterior. A sua abstrata realidade jurídico-formal não depende do tempo de produção dos preceitos'. ${ }^{25}$

O argumento produzido pelo Ministro Sepúlveda Pertence contém a essência do constitucionalismo moderno, qual seja, a de que a Constituição é a norma que sustenta toda a ordem jurídica de um Estado nacio-

22 MENDES, Gilmar Ferreira. Jurisdição constitucional: o controle abstrato de normas no Brasil e na Alemanha. 6. ed. São Paulo: Saraiva, 2014, p. 225.

23 MENDES, Gilmar Ferreira. Jurisdição constitucional: o controle abstrato de normas no Brasil e na Alemanba. 6. ed. São Paulo: Saraiva, 2014, p. 226.

24 MENDES, Gilmar Ferreira. Jurisdição constitucional: o controle abstrato de normas no Brasil e na Alemanha. 6. ed. São Paulo: Saraiva, 2014, p. 229.

25 MENDES, Gilmar Ferreira. Jurisdição constitucional: o controle abstrato de normas no Brasil e na Alemanha. 6. ed. São Paulo: Saraiva, 2014, p. 230. 
nal. Por, em tese, não haver qualquer norma supraconstitucional, ${ }^{26}$ no caso brasileiro, todas as normas que possam ser invocadas como vigentes em nosso sistema jurídico devem passar, necessariamente, pelo crivo da averiguação de validade perante a Constituição. Essa característica abrangente ou expansiva da Constituição pode ser descrita a partir do princípio da máxima efetividade, cuja hermenêutica invoca que "a uma norma constitucional deve ser atribuído o sentido que maior eficácia lhe dê". ${ }^{27}$ À densidade constitucional da proteção ao meio ambiente cultural, especialmente no âmbito dos artigos 215 e 216 da Constituição de 1988, deve se dar eficácia de natureza performativa da própria realidade deontológica do sistema jurídico, aplicando-se a técnica da interpretação conforme a Constituição.

Os defensores do posicionamento majoritário do STF no âmbito da ADI n. 2, acerca da aplicação da técnica de resolução de antinomia segundo a regra lex posterior derogat priori, esquecem de examinar questão básica no nível da hermenêutica do ordenamento jurídico: a referida regra é um método de resolução de antinomia de natureza fraca. Ela somente será concretizável se se tratar de normas de idêntica "densidade normativa", conforme aponta Gilmar Mendes, com apoio em Ipsen. ${ }^{28}$ Assim, na regra de colisão de antinomia aparente, prevalecerão as regras da hierarquia e da especialidade, de forma que o contorno interpretativo da Constituição deve privilegiar o princípio da máxima eficácia constitucional, em particular na proteção do meio ambiente cultural.

Por essa razão, a normatização constitucional aponta para o senso de aplicação do princípio da interpretação conforme a Constituição, que nada mais é que uma técnica de decisão do controle de constitucionalidade cuja finalidade principal é preservar a operação e densificação do sistema infraconstitucional, desde que este esteja devidamente adequado às cláusulas constitucionais.

Dessa maneira, verifica-se que a interpretação conforme a Constituição, no caso em análise, mostra-se inadequada para os fins pretendidos pela PGR ao ajuizar a ADPF n. 206. Veja-se que, em suas razões, a PGR arguiu que a redação do dispositivo normativo pré-constitucional é incompatível com o artigo 216, da Constituição de 1988, motivo pelo qual se apresentava anacrônico em relação a este no que se refere à compreensão de patrimônio cultural passível de proteção pelo Estado e pela coletividade. Porém, o pedido não foi pela não recepção do dispositivo normativo objeto de controle. Pelo contrário, como forma de resgatar a adequada eficácia do dispositivo normativo objeto de controle sob a vigência da Constituição de 1988, foi requerido que a ele, artigo $1^{\circ}$, do Decreto-Lei n. 25/37, fosse conferida uma interpretação conforme a Constituição, o que é contraditório em seus próprios termos.

É que a ADPF permite levar ao conhecimento do STF qualquer alegação de violação aos preceitos fundamentais decorrentes da Constituição de 1988 resultante de ato do poder público ou, quando for relevante o fundamento da controvérsia constitucional, sobre lei ou ato normativo federal, estadual ou municipal, incluídos os anteriores à Constituição. Assim, a atribuição de sentido consentâneo à Constituição ao ato objeto de controle em sede de ADPF somente pode levar ao indeferimento do pedido, posto que, se for possível ler esse ato em conformidade com a Constituição, não há de se falar em violação a preceito fundamental desta mesma Constituição.

Daí que se poderia apresentar como mais adequada para o ajuizamento da ADPF n. 206 a técnica da declaração de inconstitucionalidade sem redução de texto, outra espécie das sentenças interpretativas, ao lado da interpretação conforme a Constituição. ${ }^{29}$ Diferentemente do que se passa com a interpretação conforme

\footnotetext{
26 Um sistema constitucional atípico é o holandês. Como disserta Pedro Dallari, a Constituição Holandesa praticamente equipara os tratados internacionais às normas de hierarquia constitucional, sendo que os tratados internacionais de Direitos Humanos assumiriam, no sentido prático, hierarquia supraconstitucional, capaz de servir como elemento de controle da própria Constituição. DALLARI, Pedro B. A. Constituição e tratados internacionais. São Paulo: Saraiva, 2003, p. 33.

27 CANOTILHO, J.J. Gomes. Direito Constitucional e Teoria da Constituição. 7. ed. Coimbra: Almedina, 2003 , p. 1224.

28 MENDES, Gilmar Ferreira. Jurisdição constitucional: o controle abstrato de normas no Brasil e na Alemanha. 6. ed. São Paulo: Saraiva, 2014, p. 231.

29 Sobre isso, Cf. MEYER, Emilio Peluso Neder. Decisão e jurisdição constitucional: crítica às sentenças intermediárias, técnicas e efeitos do controle de constitucionalidade em perspectiva comparada. Rio de Janeiro: Lumen Juris, 2017, p. 72-89.
} 
a Constituição, na declaração de inconstitucionalidade sem redução de texto, procura-se declarar a inconstitucionalidade, ainda que parcial, de, pelo menos, um dos possíveis sentidos extraídos do dispositivo ou do ato normativo objeto de controle, levando ao provimento do pedido de inconstitucionalidade ou, tratando-se de direito pré-constitucional, ao provimento do pedido de não recepção. ${ }^{30}$

Logo, por meio da técnica da declaração de inconstitucionalidade sem redução de texto, o órgão do Poder Judiciário declara a inconstitucionalidade de determinada interpretação do dispositivo normativo objeto de controle. Ao invés de se estabelecer um sentido constitucional ao dispositivo normativo objeto de controle, a jurisdição constitucional exclui alguma ou algumas possibilidades de leitura daquele, por serem contrárias à Constituição. Isso quer dizer que, além de as técnicas não se confundirem, ambas possuem limites que exigem observância por parte dos órgãos do Poder Judiciário para que suas funções não sejam desvirtuadas. Dessa forma, vale a advertência de Emilio Peluso Neder Meyer no sentido de que

se existe indicação de hipóteses em que haverá uma norma inconstitucional, não há que se falar em interpretação conforme, já que o intuito desta é tornar a norma constitucional apresentando hipóteses constitucionais. Caso contrário, há alguma lógica nas técnicas utilizadas pelo STF ou seu manejo é casuístico? A não ser que a questão seja apenas terminológica, falando-se em interpretação conforme quando se quer dizer declaração de inconstitucionalidade sem redução de texto. ${ }^{31}$

Deve-se reconhecer, assim como indica o Ministro Gilmar Mendes, que as técnicas de produção de sentenças interpretativas no contexto da jurisdição constitucional são plenamente aplicáveis ao contexto da ADPF, com as devidas adequações. ${ }^{32}$ Da mesma forma, o STF, no âmbito da ADPF n. 167, conforme o informativo n. 561 do STF, citado por Gilmar Mendes, também indica que

pode ocorrer lesão a preceito fundamental fundada em simples interpretação judicial do texto constitucional. Nesses casos, a controvérsia não tem por base a legitimidade ou não de uma lei ou de um ato normativo, mas se assenta simplesmente na legitimidade ou não de uma interpretação constitucional. $^{33}$

Assim, passa-se a indicar se as normas contidas nos artigos 215 e 216 da Constituição de 1988 poderiam, de alguma maneira, se configurar como verdadeiras cláusulas instituidoras de preceitos fundamentais. Logo após, avalia-se como se deu a argumentação do Ministro Edson Fachin ao decidir a ADPF n. 206, de forma a demonstrar a sua inadequação ao contexto constitucional de argumentação, especialmente em relação à compreensão teleológica da ADPF no sistema jurídico vigente, inclusive para a proteção do meio ambiente cultural.

\subsection{0 meio ambiente cultural como preceito fundamental do sistema jurídico brasileiro}

A Constituição de 1988 inaugurou novo sistema jurídico, cuja estruturação se deu no sentido de representar a complexidade da sociedade brasileira. Ao longo do seu texto, temas das mais variadas espécies foram alçados à envergadura constitucional como forma de realizar uma tutela jurídica especial dos pontos de sustentação do Estado brasileiro. Foi nessa perspectiva que o constituinte originário previu tutela específica ao meio ambiente cultural, a partir da criação dos artigos 215 e 216 do diploma constitucional.

Como bem destaca Leonardo Barci Castriota e Guilherme Maciel Araújo, "as origens da atividade da conservação de bens culturais estão vinculadas às origens da própria tomada de consciência histórica moderna, nos finais do século XVIII". ${ }^{44}$ A conservação, como uma das inúmeras modalidades de preservação do

\footnotetext{
30 Para uma distinção entre interpretação conforme a Constituição e declaração de inconstitucionalidade sem redução do texto, Cf. TAVARES, André Ramos. Curso de direito constitucional. 10. ed. São Paulo: Saraiva, 2012, p. 295-296.

31 MEYER, Emilio Peluso Neder. Decisão e jurisdição constitucional: crítica às sentenças intermediárias, técnicas e efeitos do controle de constitucionalidade em perspectiva comparada. Rio de Janeiro: Lumen Juris, 2017, p. 75.

32 MENDES, Gilmar Ferreira. Curso de Direito Constitucional. 8. ed. São Paulo: Saraiva, 2013, p. 1261.

33 MENDES, Gilmar Ferreira. Curso de Direito Constitucional. 8. ed. São Paulo: Saraiva, 2013, p. 1224.

34 CASTRIOTA, Leonardo Barci; ARAÚJO, Guilherme Maciel. Patrimônio, valores e historiografia: a preservação do conjunto
} 
patrimônio histórico, acaba por se inserir no tempo do fenômeno filosófico iluminista, que marcou a tônica de inúmeros tipos de revoluções ao longo do século XVIII, especialmente as revoluções constitucionalistas. Não que a proteção ao patrimônio histórico já tivesse sido absorvida nessa época por cláusulas constitucionais - todas elas referenciadas, em um primeiro momento, à determinação de abstenção do Estado sobre a esfera dos direitos individuais, o que se revela como a característica central do constitucionalismo liberal. Mas, certamente, o contexto de surgimento dessa preocupação da preservação e do próprio constitucionalismo moderno parece indicar que a forma de referência ontológica do homem com o mundo começou a passar por profundas e indeléveis rupturas, a apontar novas perspectivas de interpretação do ser-no-mundo.

No caso brasileiro, o movimento de preservação dos bens culturais somente foi ter maior propulsão no início do século XX, a partir de inúmeros movimentos culturais, especialmente por parte dos artistas ligados à corrente do Modernismo, que defendiam a proteção ao patrimônio como elemento para a constituição de uma identidade nacional, cuja salvaguarda deveria ser delegada principalmente ao Estado, e não aos atores da sociedade civil, como foi o caso dos Estados Unidos da América. ${ }^{35} \mathrm{O}$ resgate das raízes do "ser brasileiro", das inúmeras peculiaridades regionais, da exuberância do meio ambiente natural, foram ingredientes imprescindíveis para interpretar não somente o significado da proteção e construção da cultura brasileira, como também para afirmar as bases espirituais e racionais sobre as quais se sustentam a tessitura social brasileira, em toda sua complexidade.

A partir dessas reflexões, que cada vez mais foram se infiltrando nas discussões sociais, o ambiente político foi sendo paulatinamente afetado por essas informações, de maneira que algumas normas começaram a ser produzidas com a finalidade de proteger o patrimônio cultural. A mais importante delas e objeto da ADPF n. 206 é certamente o Decreto-lei n. 25/37, que instituiu a Lei Geral do Tombamento. Esse marco legal, produzido no Estado Novo, partia de pressupostos hoje já superados acerca do significado de patrimônio cultural. Todavia, sua aplicabilidade se faz presente em toda a atividade administrativa do Estado no sentido de realizar a proteção do patrimônio artístico e histórico nacional. No passar dos anos e com o advento da Constituição de 1988, o rol de direitos ambientais de matriz cultural ampliou-se significativamente, de forma a abarcar tanto bens materiais como imateriais, por exemplo. No atual contexto constitucional, José Afonso da Silva aponta que

vê-se daí que, hoje, o tombamento é apenas uma das formas possíveis de proteção ao patrimônio cultural. Modernizaram-se e ampliam-se, portanto, os meios de atuação do Poder Público na tutela do patrimônio cultural. Sai-se também do limite estreito da terminologia tradicional, para utilizarem-se técnicas mais adequadas, ao falar-se em patrimônio cultural, em vez de patrimônio histórico, artístico e paisagístico, pois há outros valores culturais que não se subsumem nessa terminologia antiga. ${ }^{36}$

Nesse contexto argumentativo, importa saber se as normas constitucionais protetivas do meio ambiente cultural, especificamente as contidas nos artigos 215 e 216 da Constituição de 1988, possuem estrutura de preceitos fundamentais. Preliminarmente, cabe a identificação das normas constitucionais que servem de parâmetro para a realização do pretenso controle de constitucionalidade, ou de recepção constitucional, via ADPF:

Art. 215 - O Estado garantirá a todos o pleno exercício dos direitos culturais e acesso às fontes da cultura nacional, e apoiará e incentivará a valorização e a difusão das manifestações culturais.

Art. 216 - Constituem patrimônio cultural brasileiro os bens de natureza material e imaterial, tomados individualmente ou em conjunto, portadores de referência à identidade, à ação, à memória dos diferentes grupos formadores da sociedade brasileira, nos quais se incluem:

habitacional do Instituto de Aposentadorias e Pensões dos Industriários - IAPI.Arquitetura Revista, vol. 5, n. 1, p. 38-54, janeiro/ junho, 2009, p. 39.

35 CASTRIOTA, Leonardo Barci. História da arquitetura e preservação do patrimônio: diálogos. Anais do Museu Histórico Nacional, Rio de Janeiro, vol. 43, 2011, p. 102-103.

36 SILVA, José Afonso da. Curso de Direito Constitucional Positivo. 35 ed. Malheiros: São Paulo, 2012, p. 848. 
I - as formas de expressão;

II - os modos de criar, fazer e viver;

III - as criações científicas, artísticas e tecnológicas;

IV - as obras, objetos, documentos, edificações e demais espaços destinados às manifestações artísticoculturais;

$\mathrm{V}$ - os conjuntos urbanos e sítios de valor histórico, paisagístico, artístico, arqueológico, paleontológico, ecológico e científico.

Como se pode observar, o contexto constitucional de proteção ao meio ambiente cultural possui vasta gama de institutos e conceitos jurídico-culturais, como também de instrumentos para a implementação do programa de proteção integral a esses direitos. Frisa-se, de acordo com Luís Paulo Sirvinskas, que o rol de direitos culturais contido na Constituição é meramente exemplificativo, não havendo exaustividade. ${ }^{37} \mathrm{~A}$ partir da leitura dos dispositivos constitucionais, passa-se a ter condições de realizar uma análise crítica sobre a concepção do que seria um preceito fundamental no âmbito da Constituição e, no caso específico, apontar o meio ambiente cultural como incluído no rol desses mesmos preceitos fundamentais. A tarefa de se adensar o que seria, ou não, preceito fundamental está contida no âmbito do ônus argumentativo, cujo papel da doutrina é extremamente relevante para delinear o alcance semântico da ideia.

De acordo com os estudos de Bernardo Gonçalves Fernandes, a maior parte dos teóricos aponta que os preceitos fundamentais não são somente as cláusulas de direitos fundamentais, senão que as abarcando. Quer dizer que, para além dos direitos fundamentais topograficamente colocados na Constituição de forma explícita, outras normas seriam responsáveis pela identificação estrutural e constitutiva do próprio Estado brasileiro. Assim, apesar de a própria Constituição se comportar como norma fundamental do sistema, poder-se-ia identificar em sua estrutura normas que possuem substância estruturante de maior envergadura, enquanto que outras participam do corpo constitucional em função formal, de modo que sua pertinência e inserção poderia ser verificada em outro âmbito topográfico do sistema jurídico. Assim, os preceitos fundamentais se diferenciam de outras normas constitucionais. Mas o que seria definidor? Ensina o constitucionalista que:

a definição, sem dúvida, não é legal, trata-se de definição doutrinária e jurisprudencial. Nesses termos, os preceitos fundamentais são entendidos como aquelas normas materialmente constitucionais que fazem parte da Constituição formal. Ou seja, devem ser compreendidos como o núcleo ideológico constitutivo do Estado e da sociedade presente na Constituição formal. Em síntese, definimos os mesmos como sendo as matérias típicas fundantes do Estado e da sociedade alocadas no texto constitucional. ${ }^{38}$

Por outro lado, se se analisar a jurisprudência do STF, pode-se constatar, em inúmeros julgados, que as controvérsias envolvendo uma formulação estrutural da definição de norma constitucional tradutora de preceito fundamental são bastante obnubiladas. Exemplo disso é a profunda divisão argumentativa que se constatou na Corte, quando do julgando da ADPF n. 167, conforme se extrai do Informativo n. 561, do STF. ${ }^{39}$ Dentre suas pontuações teóricas ao longo de sua argumentação, o Ministro Gilmar Mendes fez uma digressão de grande relevância para que se leve em conta a complexidade da questão.

Também quanto ao parâmetro de controle, eu tenho feito notas, ressaltando que este talvez seja um dos grandes desafios do nosso sistema, no que diz respeito a preceito fundamental: o que seria preceito fundamental? Nós temos esse desafio. O Ministro Eros Grau ironizou que talvez devessem ter colocado o texto constitucional como um todo, mas pode ser que o constituinte tenha realmente pretendido - se teve êxito ou não, é uma outra discussão - eventualmente destacar aqui determinados postulados, determinados princípios. Isso não é, vamos dizer assim, heterodoxo. Muitos sistemas

\footnotetext{
SIRVINSKAS, Luís Paulo. Manual de Direito Ambiental. 16.ed. São Paulo: Saraiva Educação, 2018, edição eletrônica. 38 FERNANDES, Bernardo Gonçalves. Curso de Direito Constitucional. 9. ed. rev. Salvador:Juspodivm, 2017, p. 1548. 39 Supremo Tribunal Federal. Informativo n. 561, de 28 de setembro a 2 de outubro de 2009. Disponível em: < http://www.stf.jus. $\mathrm{br} /$ arquivo/informativo/documento/informativo561.htm>. Acesso em 20 de setembro de 2020.
} 
constitucionais destacam a proteção especial a determinados postulados e a determinados direitos. A própria verfassungsbeschwerde, no modelo alemão, protege os direitos fundamentais e não todo o sistema constitucional, depois o modelo desenvolve no sistema de pontos. Também o recurso de amparo, no modelo espanhol, acaba protegendo determinados postulados ou princípios. Parece-me que é nesse contexto que se coloca a nossa arguição de descumprimento de preceito fundamental. ${ }^{40}$

Constatada a controvérsia, necessário estabelecer os contornos argumentativos para verificar se o meio ambiente cultural se prefiguraria em preceito fundamental. Para se compreender o meio ambiente cultural a partir da proteção ao patrimônio cultural brasileiro realizada pela Constituição de 1988 como preceito fundamental, deve-se atentar à evolução da proteção ao patrimônio cultural no sistema jurídico posto, bem como à incorporação constitucional desses bens como normas jurídicas com teleologia específica. A redação da norma contida no art. 216 da Constituição coloca que o patrimônio cultural brasileiro é formado por bens de natureza material e imaterial. Além disso, eles se referenciam à identidade, à ação e à memória dos diferentes grupos sociais. Dessa composição de proposições complexas devem ser extraídas as proposições elementares, situadas em sua finalidade constitucional.

Se a Constituição tem a função de constituir uma sociedade e autovincular seus destinatários, ${ }^{41}$ ela encontra sua teleologia em normatizar a realidade social a partir da pretensão de mediar os fatores políticos e jurídicos em torno de normas fundantes da própria realidade factual, no agora, determinadamente referenciada. Se os direitos culturais são uma expressão da sociedade em sua realidade dinâmica, viva e inserida num contexto temporal, eles nada mais são que a representação das características da sociedade no próprio texto constitucional. A partir disso, pode-se concluir que não há Constituição sem sociedade, não há Direito sem sociedade. ${ }^{42}$ Há uma inter-relação intrínseca entre a existência da Constituição e a existência da sociedade.

É justamente pelo fato de a Constituição ser uma Constituição da sociedade que o meio ambiente cultural ganha densidade de preceito fundamental constitucional. Sem a proteção às características indispensáveis à identificação da sociedade para a qual aponta e projeta uma realização de deveres, a Constituição seria fim em si mesma e pereceria em sua função estabilizadora das distinções sociais inerentemente contidas em uma sociedade policontextural. ${ }^{43}$

Dessa maneira, a tutela constitucional às formas de expressão, modos de criar, fazer e viver, às criações científicas, artísticas e tecnológicas, às obras, aos objetos, aos documentos, às edificações, aos conjuntos urbanos e aos sítios de valor histórico, paisagístico, artístico arqueológico, paleontológico, ecológico e científico, para além de reconhecer a complexidade de características que compõem o conceito de meio ambiente cultural, também eleva à estrutura e à razão de ser do Estado brasileiro a proteção cultural. Sem essa compreensão ontológica dos pressupostos que estão por trás da criação dessas normas constitucionais, não haveria sequer que falar na continuidade da própria sociedade brasileira, pois são os fatores culturais que trazem a singularidade da ação social, que estabelecem postulados de reconhecimento e de pertença.

Logo, cada um desses conceitos abordados na normatividade constitucional comporta-se como proposições elementares da proposição complexa que se pode enunciar como proteção ao meio ambiente cultural. Por mais que seja um fenômeno de positivação constitucional relativamente recente, eles são os pressupostos lógicos de existência da própria realidade normativa constitucional. E é justamente por isso que se deve identificá-los como normas materialmente constitucionais, a ser, por decorrência lógica, instituidoras de preceitos fundamentais.

\footnotetext{
40 BRASIL. Supremo Tribunal Federal. ADPF 167 MC-REF. Rel. Min. Eros Grau. Julgamento em: 01/10/2009. DJe: 26/02/2010, p. 48-49 do inteiro teor.

41 MEYER, Emílio Peluso Neder. A decisão no controle de constitucionalidade. São Paulo: Método, 2008, p. 399.

42 LUHMANN, Niklas. O direito da sociedade. São Paulo, Martins Fontes, 2016; COSTA GONTIJO, Pedro Augusto. Os tratados internacionais comuns e a proteção da confiança. 2018. 347 f. Dissertação (Mestrado). Programa de Pós-Graduação em Direito da Universidade Federal de Minas Gerais, Belo Horizonte, 2018.

43 NEVES, Marcelo. Transconstitucionalismo. São Paulo:Wmf Martins Fontes, 2009, p. 24.
} 
O fato de se ajuizar uma ADPF com referência à proteção insuficiente que a estrutura normativa do Decreto-Lei n. 25/37 oferece ao patrimônio cultural brasileiro parece revelar aquilo que alguns estudiosos apontam como sendo a potencialização do aspecto contrafático do Direito inserido no contexto de proteção ao meio ambiente cultural. O que se busca da normatividade constitucional é a garantia de plena integralidade dos direitos, por mais que eles possam não ser devidamente observados pela prática dos sujeitos, mas especificamente pela prática do Estado. Nesse sentido, Pedro Gontijo e João Pedro Otoni indicam a dificuldade de conciliar, no atual modelo normativo brasileiro, a normatividade constitucional e o princípio da proteção integral ao meio ambiente cultural:

no que diz respeito à proteção ao patrimônio, muitas das vezes a previsão normativa traz consigo a negação do próprio fenômeno jurídico: a ineficácia e a inefetividade dos instrumentos jurídicos de proteção. É nesse ponto que reside o aspecto contrafactual do Direito, que ao mesmo tempo que tende a prospectar um cenário ideal, também traz em si a possibilidade de que a ação contrária possa ser realizada pelos indivíduos. Traz-se, então, um raciocínio de natureza binária, onde a ação positiva e a ação negativa convivem em constante correlação, antagônicas. A questão é saber: até que ponto a normatividade do Direito se amolda às expectativas que ele próprio projeta? Haveria um limite para o desapontamento do próprio Direito? ${ }^{44}$

É dentro desse contexto de compreensão argumentativa que se deve examinar a possibilidade consentânea com a realidade da proteção do direito fundamental ao patrimônio cultural. Para tanto, necessária a análise da decisão proferida pelo Ministro relator, de forma a se aplicar a base teórica aqui explanada nas considerações críticas da aplicação da ADPF em comento.

\section{A decisão monocrática proferida pelo Ministro Edson Fachin na ADPF $\mathbf{n}$. 206}

O Ministro Edson Fachin não conheceu da ADPF n. 206 ao argumento de que a controvérsia trazida no feito estaria superada pela inequívoca proteção conferida ao patrimônio cultural brasileiro em virtude da evolução normativa do Direito pátrio. Ao ter em vista que o pedido formulado pela PGR era pela recepção do artigo $1^{\circ}$, do Decreto-Lei n. 25/37, mediante interpretação conforme a Constituição, para incluir, no âmbito semântico do enunciado da norma, o conceito amplo de bem cultural, bem como para serem afastadas todas as intelecções do conceito de visibilidade que se limitem ao aspecto puramente físico do conceito, o Ministro relator do caso concluiu que o feito estaria fundado no artigo $1^{\circ}$, parágrafo único, inciso I, da Lei n. $9.882 / 90$.

Entendeu, portanto, que tão somente pelo fato de a petição impugnar dispositivo normativo pré-constitucional para fins de recepção mediante interpretação conforme a Constituição, por si só, faria com que a hipótese dos autos se enquadrasse como arguição incidental e, obviamente, não como modalidade de arguição autônoma. A própria técnica de decisão suscitada pela parte requerente para recepcionar o mencionado dispositivo impugnado seria, para o Ministro relator do caso, demonstração inequívoca de que o feito se enquadraria como arguição incidental, posto que pressuporia interpretações contrárias à Constituição. Dessa forma, restaria demonstrado que não seria o ato do poder público propriamente dito que violaria a Constituição, já que não se pretendia com a ADPF n. 206 a não recepção do artigo 1º do Decreto-Lei n. 25/37, mas, sim, o reconhecimento de integrante do ordenamento desde que a ele se conferisse interpretação compatível com a Constituição. Nem mesmo seria possível dizer que a ação atacaria decisões judiciais como atos do poder público violadores de preceitos fundamentais, pois as decisões listadas na inicial já teriam,

44 OTONI CARDOSO, João Pedro; COSTA GONTIJO, Pedro Augusto. Norma Jurídica e a proteção ao patrimônio material: eficácia e efetividade em tempos de relativização da cultura.In: Anais do I Congresso Mineiro de Direito do Patrimônio Cultural. Disponível em: <http://www.congressopatrimoniocultural.ufop.br/>. Acesso em 20 de setembro de 2020. 
inclusive, transitado em julgado.

A presente $\mathrm{ADPF}$, por se referir à recepção de ato normativo anterior à Constituição, funda-se, não na hipótese do caput, mas na do inciso I do parágrafo único, exigindo, para tanto, a comprovação da controvérsia constitucional relevante sobre a questão.

A própria natureza da técnica de "interpretação conforme" pleiteada pelo requerente demanda essa efetiva controvérsia sobre a constitucionalidade da norma, pressupondo a existência de interpretações "inconstitucionais". Ou seja, não é o ato do Poder Público que violaria preceito fundamental, como no caput, pois não pleiteia a não recepção do artigo $1^{\circ}$ do Decreto-lei n. ${ }^{\circ} 25 / 1937$. E não se pode dizer que seriam as próprias decisões citadas pelo requerente os atos violadores, pois o óbice aí reside na impossibilidade de proposição de ADPF contra decisão judicial transitada em julgado (ADPF 249 AgR, Relator(a): Min. CELSO DE MELLO, Tribunal Pleno, julgado em 13/08/2014). ${ }^{45}$

Na sequência, o Ministro Edson Fachin deixa registrado que seja para a demonstração de violação a preceito fundamental, seja para a demonstração da controvérsia constitucional relevante, exigir-se-ia que se comprovasse a existência de dissenso efetivo e atual sobre a questão tratada em sede de ADPF, sob pena de transformação do instituto em mero instrumento de consulta ao STF. Caso contrário, não haveria interesse na impugnação. Cita trecho do voto do Ministro Gilmar Mendes na ADPF n. 33 para sustentar sua afirmação no sentido de que seria preciso demonstrar controvérsia constitucional relevante pertinente ao Direito pré-constitucional para que se conheça das arguições propostas perante o Tribunal.

Assim, no caso, seja para a prova da violação do preceito fundamental (art. $3^{\circ}$, III, da Lei n. 9.882/99), seja para a prova da controvérsia judicial relevante (art. $1^{\circ}$, par. único, I), exige-se que haja demonstração do efetivo e atual dissenso sobre a questão. Trata-se de uma condição da ação sem a qual não há efetivo interesse (entendido no binômio utilidade-adequação); do contrário, a ADPF serviria como instrumento de consulta à Corte.

No julgamento da ADPF n. 33, julgado em 07/12/2005, o Ministro Gilmar Mendes fez análise histórico-jurídica acerca da possibilidade de controle abstrato do direito pré-constitucional, salientando justamente que a aprovação da Lei n. 9.882/1999 expressamente a previu de forma que: “...toda vez que se configurar controvérsia relevante sobre a legitimidade do direito federal, estadual ou municipal, anteriores à Constituição, em face de preceito fundamental da Constituição, poderá qualquer dos legitimados para apropositura de ação direta de inconstitucionalidade propor arguição de descumprimento. Também essa solução vem colmatar uma lacuna importante no sistema constitucional brasileiro, permitindo que controvérsias relevantes afetas ao direito pré-constitucional sejam solvidas pelo STF com eficácia geral e efeito vinculante". ${ }^{46}$

Diz, então, que a PGR teria juntado à inicial apenas uma decisão judicial que estaria conferindo interpretação restritiva do conceito de bem cultural para fins de proteção ao patrimônio cultural brasileiro pela interpretação do artigo $1^{\circ}$, do Decreto-Lei n. 25/37. Além disso, para o Ministro relator do caso, após a decisão judicial trazida aos autos da ADPF n. 206 como representativa da veracidade das alegações, o Brasil teria modernizado sua legislação em relação à matéria. São citados o Decreto n. 5.753/2006, que internalizou a Convenção para a Salvaguarda do Patrimônio Cultural Imaterial, à qual o Brasil aderiu em 2003, o Decreto n. 9.238/2017, o Decreto n. 7.387/2010 e passagem do sítio eletrônico oficial do Instituto do Patrimônio Histórico e Artístico Nacional (IPHAN) como demonstrativos da evolução havida na normativa protetiva do patrimônio cultural brasileiro. ${ }^{47}$

Esse fato, aliado à ausência de demonstração de proteção deficiente ao patrimônio cultural brasileiro em virtude de interpretação restritiva do conceito, justificaria o descabimento da arguição pela falta de interesse de agir. Ao final, cita ementa da decisão proferida pelo STF na ação civil originária n. 1.966, na qual teria

45 BRASIL. Supremo Tribunal Federal. ADPF 206. Rel. Min. Edson Fachin. Julgamento em: 09/03/2020. DJe: 11/03/2020. p. 7-8.

46 BRASIL. Supremo Tribunal Federal. ADPF 206. Rel. Min. Edson Fachin. Julgamento em: 09/03/2020. DJe: 11/03/2020. p.

8. (Destaques do original).

47 BRASIL. Supremo Tribunal Federal. ADPF 206. Rel. Min. Edson Fachin. Julgamento em: 09/03/2020. DJe: 11/03/2020. p. $11-14$. 
sido reconhecido que o Decreto-Lei n. 25/37 havia sido recepcionado pela Constituição de 1988 nos termos pretendidos na ADPF n. 206. Por essas razões, concluiu pelo não conhecimento da arguição em razão da ausência dos requisitos essenciais para a propositura da ação. Em face dessa decisão não foi interposto recurso de agravo interno pela requerente, motivo pelo qual o feito transitou em julgado em 13 de abril de 2020 .

Dessa forma, apesar de mencionar inúmeras normas infraconstitucionais que, em alguma medida, cumpririam a função de potencializar a proteção ao meio ambiente cultural, em conformidade com a Constituição, a argumentação do Ministro Edson Fachin parece ser realizada de forma equivocada, especialmente no que diz respeito à estrutura e teleologia normativa de procedimentalização da ação de descumprimento de preceito fundamental e sua relevância para o cumprimento dos direitos fundamentais, como o aqui tratado. É o que se passa a analisar.

\section{Apontamentos críticos à decisão proferida pelo Ministro Edson Fachin na ADPF n. 206}

É consabido que a ADPF foi regulamentada no Direito brasileiro com objetivo bem claro: "combater a chamada 'guerra de liminares". ${ }^{48}$ Esse objetivo, assumidamente admitido pelos seus mentores intelectuais, não escapou da crítica ao tempo da regulamentação do instituto, bem como no período imediatamente subsequente à edição da Lei n. 9.882/99. Destaca-se, por exemplo, a ação direta de inconstitucionalidade n. 2.231 ajuizada para questionar a constitucionalidade em bloco do novo diploma legal. ${ }^{49}$ No campo doutrinário também não faltaram críticas à forma pela qual a nova legislação disciplinou o processo e julgamento da arguição prevista pelo artigo 102, da Constituição.

Foi o caso, por exemplo, de Daniel Sarmento. Para o autor, o mencionado diploma legal vinha na esteira de outras tantas reformas legislativas promovidas pelo governo do então Presidente da República Fernando Henrique Cardoso em relação ao sistema judicial, que tinham "por objetivo, explícito ou velado, reduzir os poderes dos juízes e tribunais inferiores, reforçando a competência do Supremo Tribunal Federal, considerado mais 'confiável' pela forma política da investidura dos seus membros". Àquela época, o referido autor concluiu que "apesar dos esforços retóricos dos seus defensores em demonstrar o contrário, é cristalino que a nova ação não foi instituída para constituir instrumento de promoção da cidadania". ${ }^{50}$

O mesmo sentimento de desestima em relação à arguição é compartilhado por Gustavo Binenbojm, para quem "embora tenha sido anunciado como um instrumento de proteção dos direitos fundamentais do cidadão [...] a verdade é que a arguição brasileira, tal como regulamentada pela Lei n. 9.882/99 (sobretudo após os vetos do Presidente da República ao projeto aprovado pelo Congresso Nacional), ficou mais para avocatória do que para ação constitucional". Para Binenbojm, "o novo remédio vem tornar ainda mais complexo — talvez mais confuso — o já eclético sistema de jurisdição constitucional brasileiro". ${ }^{51}$

No entanto, temperando o posicionamento inicial de Binenbojm, é bom que se diga que "apesar de fundado temor inicial, é certo também que ela não se prestou, ao menos nesses primeiros anos, a uso análogo

\footnotetext{
48 MENDES, Gilmar Ferreira. Arguição de Descumprimento de Preceito Fundamental ( $\$ 1^{\circ}$ do art. 102 da Constituição Federal). In: Repertório de jurisprudência, n. 04, fev., 2000, p. 114.

49 Até a data de fechamento deste texto, não houve decisão do STF na ADI n. 2.231, nem em sede cautelar nem de mérito. É bom que se diga que em 2018 houve decisão resolvendo questão de ordem com a conversão do julgamento cautelar em diligência, de modo a possibilitar a devida instrução do feito para que ele tenha uma decisão meritória final, e não precária.

50 SARMENTO, Daniel. Apontamentos sobre a arguição de descumprimento de preceito fundamental.In:Revista de Direito Administrativo, Rio de Janeiro, n. 224, abr/jun, 2001, p. 96.

51 BINENBOJM, Gustavo. A nova jurisdição constitucional: legitimidade democrática e instrumentos de realização. 4. ed. Rio de Janeiro: Renovar, 2014, p. 242-243.
} 
ao da extinta avocatória, existente no direito constitucional brasileiro do regime militar". ${ }^{52}$ Dessa maneira, nem a ação avocatória tampouco o efeito avocatório por vias transversas encontrou guarida sob a Constituição de $1988 .^{53}$ Apesar de todas as críticas, a arguição não apenas tornou mais complexo ou mais confuso o sistema de controle jurisdicional de constitucionalidade das leis brasileiro. Ela se apresenta como alternativa para acrescentar novas possibilidades de tutela a importantes valores constitucionais que não encontravam guarida nos sistemas de controle concentrado e difuso de constitucionalidade até então em vigor no país. Sua tutela se refere não à Constituição total, mas exclusivamente às cláusulas constitucionais constitutivas de preceitos fundamentais.

Muito embora crítico à forma pela qual a Lei n. 9.882/99 disciplinou as regras de processo e julgamento da ADPF, Daniel Sarmento, ainda no início dos anos 2000, vislumbrou a possibilidade de salvar o instituto. Sua aposta era no papel da jurisprudência e da doutrina que, imbuídas de "vontade de constituição" e afastando-se de dogmas e preconceitos antigos, poderiam interpretar o novo instituto com os olhos voltados para as reais necessidades da jurisdição constitucional do país e, assim, concretizar algumas das promessas até então não cumpridas da Constituição, aproveitando-se das potencialidades exegéticas da lei. ${ }^{54}$

Isso porque, por mais que a vontade da lei aponte para uma defesa da governabilidade e não para a defesa da cidadania, a interpretação constitucional não se reduz na busca de uma suposta intenção do legislador oculta no texto da lei. O Direito possui uma estrutura que lhe é própria, isto é, trata-se de sistema impessoal dotado de normatividade inerente ao seu texto. A Constituição e o sistema de direitos por ela instituído se apresentam como projeto de construção de uma sociedade democrática em direção a um futuro de mais e iguais direitos de liberdade e igualdade que contam, inclusive, com mecanismos para sua defesa e reconhecimento.

É nesse contexto que deve ser analisado o novo instituto: se o Estado Democrático de Direito é um plus normativo em relação às duas formas anteriores de Estado de Direito (Liberal e Social), a arguição de descumprimento de preceito fundamental é um plus normativo em relação aos institutos de proteção aos direitos fundamentais previstos pelo texto constitucional..$^{55}$

Ao lado das ações especiais do controle concentrado de constitucionalidade (ação direta de inconstitucionalidade, ação direta de inconstitucionalidade por omissão e ação declaratória de constitucionalidade), dos remédios constitucionais (habeas corpus, habeas data, mandado de segurança, mandado de injunção e ação popular) e do sistema de controle difuso de constitucionalidade da tradição do constitucionalismo republicano brasileiro, o constituinte originário colocou à disposição da cidadania a ADPF para defesa de preceitos fundamentais decorrentes da Constituição. A forma pela qual o artigo 102, parágrafo $1^{\circ}$, da Constituição, foi regulamentado pela Lei n. 9.882/99, permite à doutrina classificar o instituto como "uma forma sui generis de controle de constitucionalidade". ${ }^{56}$

Nos termos da lei, além de poder ser ajuizada de forma autônoma para questionar qualquer ato do poder público que ameace de lesão ou que lese preceito fundamental decorrente da Constituição, também é cabível a ação quando, por exemplo, houver decisão judicial afrontosa aos preceitos fundamentais protegidos em sede constitucional em virtude da interpretação de ato normativo federal, estadual ou municipal, até mesmo anteriores à Constituição, desde que as partes do processo representem, juntamente à PGR, solicitando a propositura da arguição. Em ambos os casos, a decisão proferida pelo STF possui efeitos erga omnes e eficácia vinculante para a Administração Pública e para os demais órgãos judiciais do país. Por isso, Lenio Streck

52 BARROSO, Luís Roberto. Controle de constitucionalidade no direito brasileiro: exposição sistemática da doutrina e análise crítica da jurisprudência.7. ed. São Paulo: Saraiva, 2016, p. 323.

53 Para uma reflexão nesse sentido, Cf. STRECK, Lenio Luiz. Jurisdição constitucional. 5. ed. Rio de Janeiro: Forense, 2018, p. 544546.

54 SARMENTO, Daniel. Apontamentos sobre a argüição de descumprimento de preceito fundamental. In: Revista de Direito Administrativo, Rio de Janeiro, n. 224, abr/jun, 2001, p. 116.

55 STRECK, Lenio Luiz. Jurisdição constitucional. 5. ed. Rio de Janeiro: Forense, 2018, p. 528.

56 STRECK, Lenio Luiz. Jurisdição constitucional. 5. ed. Rio de Janeiro: Forense, 2018, p. 521. 
afirma que "a ADPFconfigura modalidade de integração entre os modelos difuso e concentrado no Supremo Tribunal Federal". ${ }^{57}$

A mesma conclusão pode ser extraída do voto proferido pelo Ministro Gilmar Mendes na ADPF n. 33. Segundo o Ministro, a arguição permite que o STF aprecie questões que não poderiam ser apreciadas em sede de controle abstrato de constitucionalidade, tais como o direito municipal, as normas pré-constitucionais e os atos normativos secundários. Por outro lado, a arguição permite igualmente que se leve ao conhecimento da Corte, por uma espécie de incidente de inconstitucionalidade, controvérsias constitucionais relevantes em discussão em processos judiciais que somente chegariam ao Tribunal após longos anos de tramitação nas instâncias inferiores do Judiciário pela via do recurso extraordinário. Daí a necessidade de se compreender o caráter subsidiário da ação a partir de um enfoque predominantemente objetivo, isto é, como ausência de outro meio processual eficaz para proteção da ordem constitucional de forma ampla, geral e imediata. ${ }^{58}$

Essa discussão sobre as possibilidades de tutela da ordem constitucional objetivamente considerada, que pode ser viabilizada por meio da arguição, conforme visto na seção anterior deste trabalho, está sob pano de fundo da razão de decidir utilizada pelo Ministro Edson Fachin na ADPF n. 206. O Ministro relator do caso considerou que tão somente pelo fato de a PGR questionar a compatibilidade do direito pré-constitucional em face da Constituição de 1988 faria com que o feito se enquadrasse, automaticamente, na hipótese prevista pelo artigo $1^{\circ}$, parágrafo único, inciso I, da Lei n. 9.882/99, fazendo do mesmo uma arguição incidental, ou seja, desvirtuando do pleito encaminhado. Além disso, o pedido de recepção do dispositivo impugnado mediante a técnica da interpretação conforme a Constituição demonstraria inequivocamente que o que a requerente alegava violar a ordem constitucional não seria o artigo citado propriamente dito, mas as interpretações dadas a ele, estas sim, marcadas pela pecha da "inconstitucionalidade".

Por essa razão, como não havia pedido de não recepção do artigo $1^{\circ}$, do Decreto-Lei n. 25/37, não seria ele que estaria a violar preceito fundamental decorrente da Constituição de 1988. Tampouco poderiam ser as decisões judiciais anexadas à inicial, pois as mesmas já teriam transitado em julgado, o que afastaria o cabimento da ação nos termos da jurisprudência do STF. Diante desse cenário, conclui que além da demonstração da violação a preceito fundamental, seria preciso demonstrar na ADPF n. 206 a existência de controvérsia judicial relevante, efetiva e atual sobre a questão colocada na demanda.

Ao que parece, faltou à decisão a devida compreensão das espécies de arguição previstas pelo artigo $1^{\circ}$, da Lei n. 9.882/99, bem como das espécies das sentenças interpretativas que, ao final, resultou em proteção deficiente à ordem constitucional malferida pelo dispositivo normativo impugnado e à dogmática de proteção aos direitos fundamentais. É o que se passa a demonstrar na sequência.

A arguição autônoma, prevista pelo caput do artigo $1^{\circ}$ da Lei n. 9.882/99, é típica hipótese de controle abstrato de constitucionalidade ao lado da ação direta de inconstitucionalidade, da ação direta de inconstitucionalidade por omissão e da ação declaratória de constitucionalidade, devendo ser manejada quando estas não se mostrarem aptas à defesa da ordem constitucional objetivamente considerada, nos casos de ameaça de lesão ou de lesão propriamente dita a preceito fundamental decorrente da Constituição.

A arguição incidental, por sua vez, prevista pelo inciso I, do parágrafo único, do artigo $1^{\circ}$, da Lei n. 9.882/99, destina-se a levar ao conhecimento do STF controvérsia constitucional relevante que esteja sendo objeto de discussão perante qualquer juízo ou tribunal do país, inexistindo, também, nessa hipótese, qualquer outro meio apto a enfrentar a ameaça de lesão ou a lesão propriamente dita a preceito fundamental. Nesse caso, o STF apreciará tão somente a questão constitucional levada à sua jurisdição, apartando-a do caso concreto no qual o incidente de inconstitucionalidade fora suscitado. Em virtude dos efeitos erga omnes e da eficácia vinculante, não apenas o caso concreto no qual o incidente fora suscitado, mas também todos

\footnotetext{
STRECK, Lenio Luiz. Jurisdição constitucional. 5. ed. Rio de Janeiro: Forense, 2018, p. 521.

58 BRASIL. Supremo Tribunal Federal. ADPF 33. Rel. Min. Gilmar Mendes. Julgamento em: 07/12/2005. DJe: 27/10/2006, p.
} 3-41. 
os outros casos que discutam a mesma ratio decidendi serão aplicados conforme a solução apresentada pela Corte à questão constitucional. O incidente poderá ser suscitado por qualquer um dos legitimados à propositura da ação direta de inconstitucionalidade do artigo 103, da Constituição, assim como pelo Procurador Geral da República, mediante representação das partes do processo em curso nas instâncias ordinárias de jurisdição.

Após o veto presidencial aposto ao artigo $2^{\circ}$, inciso II, da Lei n. 9.882/99, não superado pelo Congresso Nacional, restou vedado às partes do processo levar imediatamente o incidente de inconstitucionalidade à apreciação do STF, não obstante seja-lhes admitido representar à PGR, conforme dispõe o artigo $2^{\circ}$, parágrafo $1^{\circ}$, da Lei em exame. Nesses termos, agora, as duas espécies de arguição possuem os mesmos legitimados ativos, o que inegavelmente "conduz a um esvaziamento da arguição incidental" ${ }^{59}$ Em sua modalidade incidental, a arguição exige, para ser conhecida, que, além da prova da violação a preceito fundamental, demonstre-se, também, a existência de controvérsia judicial relevante sobre a aplicação do preceito fundamental que se considera violado, sendo, pois, mais custosa para o arguente.

É importante registrar que há uma diferença entre aquilo que se pode denominar arguição de descumprimento de preceito fundamental autônoma, que se aproxima da modalidade de controle abstrato de constitucionalidade, e a forma incidental de manejo da ADPF. Assim, no primeiro caso, é preciso tão somente comprovar a inexistência de outros meios para solver a controvérsia (com os necessários aportes hermenêuticos que essa questão merece, já especificados anteriormente); no segundo caso, a essa exigência agrega-se a comprovação da relevância da questão. Mas, mais do que a comprovação da relevância, há que estar provada a violação de preceito fundamental. ${ }^{60}$

Isso quer dizer que, o que distingue as duas espécies de arguição, a autônoma e a incidental, é a forma pela qual estas são levadas à apreciação do STF. Aquela independe da existência de controvérsia judicial instaurada perante os juízos e tribunais do país para a sua propositura, enquanto para esta é imprescindível que se demonstre a existência de tal controvérsia como requisito indispensável ao conhecimento da ação. Diferentemente, portanto, do que constatado na ADPF n. 206, que foi enquadrada na hipótese de arguição incidental tão somente pelo fato de pretender a recepção do artigo $1^{\circ}$, do Decreto-Lei n. 25/37, pela Constituição de 1988, mediante a técnica da interpretação conforme a Constituição.

Não é porque apenas o inciso I, do parágrafo único, do artigo $1^{\circ}$, da Lei n. 9.882/99, faz menção à propositura da arguição tendo por objeto ato normativo anterior à Constituição, que somente a arguição autônoma pode enfrentar o direito pré-constitucional. Ambas as espécies podem se voltar à tarefa de enfrentar a compatibilidade de normas pré-constitucionais com a Constituição, em virtude do caráter subsidiário da ação que não se restringe ou faz distinção entre as suas modalidades autônoma ou incidental. Dessa maneira, é perfeitamente possível ajuizar uma arguição autônoma tendo por objeto norma anterior à Constituição, já que o objeto dessa modalidade da ação não se limita ao direito municipal ou às espécies normativas secundárias. Conforme a lição de Luís Roberto Barroso, "daí a razão de a ADPF preencher um vazio relativamente à sindicabilidade dos atos normativos anteriores à Constituição, como explicitado na parte final do art. $1^{a}$, parágrafo único, II, mas válido para a arguição autônoma e incidentall". ${ }^{61}$

Dessa forma, o que distingue a arguição autônoma da incidental não é o objeto da ação, tampouco a técnica de decisão que fundamenta o pedido, como pretendeu fazer valer o Ministro Edson Fachin, mas a origem da ameaça de lesão ou da violação a preceito fundamental decorrente da Constituição. Na autônoma, o contraste entre o ato normativo objeto de controle e a Constituição se dá de forma inicial, independentemente da existência de controvérsia judicial em curso. Na incidental, por sua vez, é necessário que haja interpretação jurisdicional do ato normativo objeto de controle com potencial de lesar preceito fundamental

\footnotetext{
59 BARROSO, Luís Roberto. Controle de constitucionalidade no direito brasileiro: exposição sistemática da doutrina e análise crítica da jurisprudência.7. ed. São Paulo: Saraiva, 2016, p. 345.

60 STRECK, Lenio Luiz. Jurisdição constitucional. 5. ed. Rio de Janeiro: Forense, 2018, p. 534-535.

61 BARROSO, Luís Roberto. Controle de constitucionalidade no direito brasileiro: exposição sistemática da doutrina e análise crítica da jurisprudência.7. ed. São Paulo: Saraiva, 2016, p. 351.
} 
em um caso concreto. É justamente por isso que os criadores da arguição conferiram à ação a missão de combater a chamada "guerra de liminares".

Daí que não sendo proveniente de caso concreto representativo de controvérsia judicial existente perante os órgãos jurisdicionais do país era irrelevante, para fins da ADPF n. 206, a demonstração de controvérsia judicial atual e efetiva sobre a questão da proteção ao patrimônio cultural, como forma de adensar a própria ideia de meio ambiente cultural. Tal fato, aliás, foi informado pela PGR em manifestação nos autos anterior à decisão proferida. Além do mais, é um tanto quanto questionável a interpretação restritiva conferida pelo Ministro relator do caso à expressão "controvérsia judicial” do artigo $1^{\circ}$, parágrafo único, inciso I, da Lei n. 9.882/99. Reduzir o sentido da expressão ao número de casos em discussão perante os órgãos judiciais do país vai de encontro à pretensão de tornar a $\mathrm{ADPF}$ como verdadeiro instrumento processual para a defesa da ordem constitucional objetivamente considerada. Somando-se a isso o veto presidencial aposto ao artigo $2^{\circ}$, inciso II, da Lei n. 9.882/99, vislumbra-se uma aproximação entre as duas modalidades, o que, obviamente, não equipara a arguição autônoma à incidental, nem tampouco autoriza que os requisitos exigidos para a propositura de uma sejam aplicáveis à propositura da outra.

Como se assinalou anteriormente, o papel da arguição incidental de descumprimento de preceito fundamental restou minimizado na Lei n. 9.882/99. Não sendo suscitável pelas partes do processo ou por qualquer pessoa lesada ou ameaçada por ato do Poder Público, a legitimação para essa arguição recai sobre as mesmas pessoas e órgãos que podem propor a arguição autônoma. Como regra, portanto, dificilmente optarão elas pela via incidental. Nada obstante, a arguição incidental permanece vigente no ordenamento e, para seu cabimento, a lei exige um requisito adicional: a relevância do fundamento da controvérsia constitucional sobre lei ou ato normativo, que pode ser de qualquer uma das três esferas de Poder, incluindo os editados anteriormente à Constituição. Como regra, estará em discussão a constitucionalidade do ato normativo em questão, em caráter geral ou em alguma de suas incidências específicas.

Embora a motivação imediata de quaisquer dos legitimados possa ser a eventual tutela de uma situação específica - agindo, portanto, como um substituto processual do verdadeiro interessado -, deverá ele demonstrar ser relevante a controvérsia quando o seu deslinde tiver uma repercussão geral, que transborde o interesse das partes em litígio, seja pela existência de um número expressivo de processos análogos, seja pela gravidade ou fundamentalidade da tese em discussão, por seu alcance político, econômico, social ou ético. Por vezes, a reparação imediata de uma injustiça individual terá uma valia simbólica decisiva para impedir novas violações. Seja como for, na arguição incidental, mesmo que estejam em jogo direitos subjetivos, haverá de estar envolvida situação que afete o ordenamento constitucional de maneira objetiva. ${ }^{62}$

Por outro lado, Barroso indica que a arguição autônoma possui contornos próprios, funcionando como verdadeiro instrumento para a proteção da ordem jurídica objetiva pré-constitucional, a partir da averiguação de parametricidade dessas normas em face da Constituição. Assim,

no caso da arguição autônoma, além do pressuposto geral da inexistência de qualquer outro meio eficaz de sanar a lesividade (o que lhe dá um caráter de subsidiariedade), exige-se (i) a ameaça ou violação a preceito fundamental e (ii) um ato estatal ou equiparável capaz de provocá-la. Trata-se, inequivocamente, de uma ação, análoga às ações diretas já instituídas na Constituição, por via da qual se suscita a jurisdição constitucional abstrata e concentrada do Supremo Tribunal Federal. A legitimação é a mesma da ação direta de inconstitucionalidade, o parâmetro de controle é mais restrito - não é qualquer norma constitucional, mas apenas preceito fundamental - e o objeto do controle é mais amplo, pois não se limita aos atos normativos e estende-se aos três níveis de poder. ${ }^{63}$

Dessa maneira, pode-se identificar que a ADPF autônoma tem como teleologia resguardar a higidez da ordem constitucional a partir de cláusulas específicas, os denominados preceitos fundamentais. Como abor-

62 BARROSO, Luís Roberto. Controle de constitucionalidade no direito brasileiro: exposição sistemática da doutrina e análise crítica da jurisprudência.7. ed. São Paulo: Saraiva, 2016, p. 340-341.

63 BARROSO, Luís Roberto. Controle de constitucionalidade no direito brasileiro: exposição sistemática da doutrina e análise crítica da jurisprudência.1. ed. São Paulo: Saraiva, 2004, p. 220. 
dado anteriormente, a identificação dos preceitos fundamentais da Constituição de 1988 é tema de grande controvérsia e também objeto de grandes debates teóricos, inclusive no âmbito do próprio STF. Exemplo disso pode ser constatado quando do julgamento da ADPF n. 167, em que a maior parte dos Ministros anuiu à tese suscitada pelo Ministro Ayres Britto, defendendo que os preceitos fundamentais constitucionais estariam ligados a uma análise taxonômica e topográfica dentro do próprio texto constitucional. Assim, sustentou que "a Constituição me parece autoexplicativa. O preceito fundamental é aquele que a Constituição diz ser fundamental, adjetivado de fundamental. O Título I, por exemplo. Tudo que se contém ali é fundamental, porque a Constituição diz 'Dos princípios Fundamentais" ". ${ }^{64}$ Essa posição já não é defendida pela maior parte da doutrina e até mesmo por grande parte dos Ministros do STF em sua atual composição, havendo a abordagem dos preceitos fundamentais para além daquilo que a Constituição denomina como sendo "fundamental", inter-relacionando-se com a própria estrutura do Estado Federal e da sociedade brasileira. ${ }^{65}$

No que se refere ao tratamento conferido à interpretação conforme a Constituição pela decisão monocrática proferida na ADPF n. 206, constata-se que uma indevida compreensão da técnica da interpretação conforme a Constituição pelo Ministro relator do caso foi utilizada como fundamento para enquadramento do feito na hipótese do artigo $1^{\circ}$, parágrafo único, inciso I, da Lei n. 9.882/99. Tão somente pelo fato de a PGR ter pretendido a recepção do artigo $1^{\circ}$, do Decreto-Lei n. 25/37, mediante interpretação conforme a Constituição, o Ministro Edson Fachin concluiu ser o caso de arguição incidental, que pressuporia apenas e tão somente interpretações provenientes de órgãos jurisdicionais.

Na tradição do Direito Constitucional brasileiro, a nulidade do diploma legal infraconstitucional seria decorrência lógica e inevitável da constatação de sua incompatibilidade com a Constituição. Nesse sentido, quando juízes e tribunais se convenciam, em qualquer dos processos de constitucionalidade das leis, sobre a inconstitucionalidade de determinado diploma normativo infraconstitucional, vincular-se-ia, "dessarte uma situação — a inconstitucionalidade — à consequência jurídica — nulidade" ${ }^{66}$ A ruptura paradigmática promovida pelo advento do Estado Social alterou o papel desempenhado pelo Poder Judiciário repercutindo, inevitavelmente, no exercício da jurisdição constitucional e no controle de constitucionalidade por ela desenvolvido. ${ }^{67}$

Em compasso com as inovações introduzidas no campo do controle jurisdicional de constitucionalidade das leis, principalmente após a Segunda Guerra Mundial, observaram-se mudanças na conformação jurídico-constitucional do controle de constitucionalidade no Direito Constitucional brasileiro. Seguindo tais mudanças, a Lei n. 9.868/99 incluiu alterações significativas às decisões proferidas pelo STF em sede de controle concentrado de constitucionalidade. Além da possibilidade de modulação temporal dos efeitos da decisão, destaca-se o reconhecimento da possibilidade do manejo das sentenças interpretativas no exercício desta tarefa. A jurisprudência do STF já reconheceu a possibilidade de extensão dessas técnicas à ADPF e ao controle difuso de constitucionalidade.

As sentenças interpretativas, como espécie das sentenças intermediárias, almejam salvar, pela via da interpretação, determinado ato normativo do vício da inconstitucionalidade. Ou seja, procura-se verificar a possibilidade de a norma impugnada permanecer no ordenamento jurídico dando-lhe interpretação que seja compatível com a Constituição. Parece evidente, pois, que as sentenças interpretativas pressupõem a existência de diferentes possibilidades hermenêuticas que podem ser conferidas ao ato normativo objeto de controle e que essas interpretações não necessariamente precisam ser provenientes única e exclusivamente

BRASIL. Supremo Tribunal Federal. ADPF 167 MC-REF. Rel. Min. Eros Grau. Julgamento em: 01/10/2009. DJe: 26/02/2010. FERNANDES, Bernardo Gonçalves. Curso de Direito Constitucional. 9. ed. rev. Salvador, Juspodivm, 2017, p. 1548.

MENDES, Gilmar Ferreira. Jurisdição constitucional: o controle abstrato de normas no Brasil e na Alemanha. 5. ed. São Paulo: Saraiva, 2005, p. 254.

67 Sobre isso, Cf. MEYER, Emilio Peluso Neder. Decisão e jurisdição constitucional: crítica às sentenças intermediárias, técnicas e efeitos do controle de constitucionalidade em perspectiva comparada. Rio de Janeiro: Lumen Juris, 2017, p. 2. 
de órgãos jurisdicionais, já que estes, apesar de relevantes, não são os únicos intérpretes autorizados da Constituição.

Por isso, não se afigura razoável restringir o manejo das sentenças interpretativas apenas às hipóteses de interpretações conferidas pelos órgãos jurisdicionais do país, tal como feito pelo Ministro Edson Fachin na ADPF n. 206, sob pena de frustrar o projeto de construção de uma sociedade aberta dos intérpretes da Constituição (HÄBERLE, 1997). Ademais, pouco importa que não se tenha comprovado a existência atual e efetiva de interpretações que tenham restringido a compreensão de bem cultural, na visão constitucional de meio ambiente cultural, para fins de proteção em contrariedade com o que dispõe a Constituição, nem tampouco a evolução do sistema jurídico-normativo pátrio relativo à matéria.

Isso porque, tratando-se de processo de índole marcadamente abstrata, vocacionado à proteção da ordem constitucional objetivamente considerada, a ADPF n. 206 pretendia evitar um retorno ao status quo ante por meio de decisão dotada de efeito erga omnes e eficácia vinculante, a fim de excluir uma possibilidade interpretativa perfeitamente possível do artigo $1^{\circ}$, do Decreto-Lei n. 25/37, que representaria, inegavelmente, uma proteção deficiente do bem jurídico tutelado pelo artigo 216, da Constituição, qual seja, o patrimônio cultural brasileiro, inserido na órbita de proteção do meio ambiente cultural.

No que se refere aos novos diplomas legais editados e incorporados ao Direito brasileiro, eles evidenciam, antes de qualquer coisa, justamente a defasagem da compreensão de patrimônio cultural do artigo $1^{\circ}$, do Decreto-Lei n. 25/37. Assim, a necessidade de se conferir a esse dispositivo normativo uma leitura que seja consentânea com a Constituição, por meio dos efeitos erga omnes e da eficácia vinculante da decisão proferida em sede de controle concentrado de constitucionalidade, de forma que seja possível evitar interpretações desviantes da atual ordem constitucional brasileira.

A inauguração de capítulo específico na Constituição para realizar a proteção ao meio ambiente cultural revela uma nova compreensão da nossa sociedade sobre a importância de proteger bens jurídicos de caráter substancial para o autorreconhecimento de nossas origens, de nossa identidade. Há aqui o resguardo dos referenciais das múltiplas dimensões da vida comunitária, que não somente se apresentam na própria produção cultural, como também política. Dessa maneira, como ensinam Leuzinger e Cureau, a ideia de preservação do direito fundamental ao patrimônio cultural como forma de expansão da própria ideia de meio ambiente cultural acaba por revelar a composição múltipla da tessitura social brasileira, salientando-se aquilo que possui significado espiritual e, por via de consequência, é identificado como da mais alta importância coletiva. ${ }^{68}$ A Constituição, então, passa a tutelar para além da criação econômica do homem e da sua relação com a natureza, de forma a incorporar à normatividade constitucional uma matriz de meio ambiente que se integra à obra humana, em sua mais alta significação ontológica.

Em razão da normatividade constitucional, pelo menos uma decisão deveria ter sido proferida pelo STF no caso em estudo, justamente para evitar, no marco da atual Constituição, interpretações que restrinjam o conceito de bem cultural para fins de proteção pelo Estado e pela coletividade ao estágio anterior à sua promulgação. Para essa finalidade, ao invés da interpretação conforme a Constituição, melhor seria o socorro à técnica da declaração de inconstitucionalidade sem redução de texto, como acima defendido.

É que em sede de ADPF o que se pede é que o STF reconheça que o ato normativo objeto de controle de fato esteja ameaçando de lesão ou esteja violando preceito fundamental decorrente da Constituição. Em outras palavras, pretende-se que se reconheça uma situação de incompatibilidade entre o parâmetro do controle e o seu objeto, finalidade que é alcançada pela declaração de inconstitucionalidade sem redução de texto, que extirpa do ordenamento jurídico determinada interpretação do ato normativo infraconstitucional em razão da sua incompatibilidade com a Constituição, enquanto a interpretação conforme a Constituição almeja justamente o contrário, ou seja, harmonizar o objeto de controle com o seu parâmetro mediante

${ }_{68}$ LEUZINGER, Márcia Dieguez; CUREAU, Sandra. Direito ambiental. Rio de Janeiro:Elsevier, 2008, p. 27-28. 
determinada interpretação. O ponto comum entre ambas, porém, é a manutenção do ato normativo objeto de controle por meio de interpretação que o torne válido perante a ordem constitucional em vigor. Pecou o Ministério Público Federal na técnica processual de elaboração do pedido em face da utilização da técnica inconstitucionalidade sem redução de texto. Deixou de reafirmar a vontade constitucional o Ministro Edson Fachin ao compor decisão de caráter estritamente pragmático que se traduz em esvaziamento das técnicas processuais e hermenêuticas de defesa da Constituição, a realizar, nesse caso, proteção insuficiente ao patrimônio cultural brasileiro por parte da Suprema Corte.

\section{Considerações finais}

O presente trabalho teve como objetivo explorar os limites e as possibilidades da tese lançada pela decisão monocrática proferida pelo Ministro Edson Fachin para não conhecer e, portanto, para extinguir sem resolução de mérito a ADPF n. 206, à luz dos sistemas de controle de constitucionalidade e de proteção aos direitos fundamentais instituídos pela Constituição de 1988. Após análise do caso em questão, foi possível vislumbrar que faltou à decisão a devida compreensão das espécies de arguição previstas pelo artigo $1^{\circ}$, da Lei n. 9.882/99, bem como das espécies das sentenças interpretativas, que, ao final, resultou em uma proteção deficiente à ordem constitucional malferida pelo dispositivo normativo impugnado e à dogmática de proteção aos direitos fundamentais, especificamente relativos ao meio ambiente cultural.

A partir da promulgação da Constituição de 1988, vislumbrou-se uma ruptura paradigmática da compreensão de patrimônio cultural para fins de proteção pelo Estado e pela coletividade para incluir em tal conceito bens não apenas de natureza material, mas também de natureza imaterial relacionados à identidade, à ação, à memória dos diferentes grupos formadores da sociedade brasileira. A ampliação da noção de bem cultural pelo próprio texto constitucional indica novo padrão de proteção ao patrimônio cultural incluindo-o inegavelmente no rol dos direitos fundamentais de terceira dimensão, de titularidade transindividual e difusa ${ }^{69}$ tanto que pode ser tutelado pela via da ação popular e da ação civil pública. Faz parte, então, daquilo que se denomina meio ambiente cultural.

É preciso reconhecer que a classificação dos direitos fundamentais segundo o critério denominado constitucional-literal "é por demais míope por não reconhecer a existência de direitos fundamentais em outras partes do texto constitucional". ${ }^{70}$ Além disso, opróprio STF já reconheceu a existência de direitos fundamentais para além do agrupamento contido na organização textual da Constituição, isto é, para além do rol compreendido entre os artigos $5^{\circ}$ e 17 da Constituição. ${ }^{71}$

Isso quer dizer, portanto, que os direitos fundamentais somente podem assim ser reconhecidos nas situações concretas de aplicação, ou seja, à luz dos casos concretos colocados para apreciação judicial, a partir do uso argumentativo das partes em litígio, hipótese na qual será possível estabelecer as proporções e os significados do direito em debate. Por fim, em uma leitura paradigmática da questão das dimensões dos direitos fundamentais, uma nova dimensão não exclui a anterior e tampouco significa mero acréscimo de novos direitos ao texto constitucional, mas a redefinição do sentido e do conteúdo dos direitos anteriormente fixados. Por tais razões, não apenas o direito infraconstitucional tem de ser lido à luz da nova concepção de patrimônio cultural adotada pela Constituição de 1988, mas também todo o sistema de direitos fundamentais deve ser compatibilizado e harmonizado com esta nova concepção. ${ }^{72}$

69 Sobre isso, Cf. VARELLA, Guilherme. Plano Nacional de Cultura: direitos e politicas culturais no Brasil. Rio de Janeiro: Azougue, 2014 , p. 64.

70 FERNANDES, Bernardo Gonçalves. Curso de direito constitucional. 9. ed. Salvador: Juspodivm, 2017, p. 324.

71 Sobre isso, veja-se: BRASIL. Supremo Tribunal Federal. ADI 939. Rel. Min. Sidney Sanches. Julgamento em: 15/12/1993. DJ: 18/03/1994.

${ }^{72}$ Para uma leitura paradigmática da questão das dimensões dos direitos fundamentais, Cf. CATTONI DE OLIVEIRA, Marcelo 
Daí não parece restar dúvidas que a decisão monocrática proferida pelo Ministro Edson Fachin na ADPF n. 206 representou uma hipótese de proteção deficiente a bem jurídico tutelado constitucionalmente. Ao extinguir o feito sem resolução do mérito da questão, o STF, por meio da decisão proferida pelo Ministro relator do caso, deixou de fixar interpretação adequada do ponto de vista constitucional ao artigo $1^{\circ}$, do Decreto-Lei n. 25/37, que inegavelmente se mostra ultrapassado pela nova compreensão de bem cultural assumida pelo constituinte originário. Sem uma decisão com efeitos erga omnes e eficácia vinculante torna-se possível, mesmo passados mais de trinta anos de promulgação da Constituição, e com toda a evolução da normativa de proteção ao patrimônio e ao meio ambiente cultural a partir do novo paradigma democrático, interpretações que contrariem a vontade constituinte expressa pelos artigos 215 e 216 da Constituição.

Além do mais, defendeu-se que a natureza jurídica do provimento jurisdicional em sede de ADPF, no que se refere ao manejo das sentenças interpretativas, deveria ter levado a PGR a realizar pedido de declaração de inconstitucionalidade sem redução de texto, tendo em vista que a finalidade mais adequada seria realizar o controle do artigo $1^{\circ}$, do Decreto-Lei n. 25/37 em face dos preceitos constitucionais, extirpando algum de seus significados que seriam considerados inconstitucionais. Dessa maneira, os instrumentos de controle concentrado, cujos pedidos giram em torno de sentença interpretativas, devem ser pensados conforme a natureza jurídica do objeto de controle, da técnica de controle e do instrumento de controle, sob pena de não se atingir o objetivo de proteção à normatividade constitucional por aspectos meramente processuais e formais.

\section{Referências}

BARROSO, Luís Roberto. Controle de constitucionalidade no direito brasileiro: exposição sistemática da doutrina e análise crítica da jurisprudência. 1. ed. São Paulo: Saraiva, 2004.

BARROSO, Luís Roberto. Curso de direito constitucional contemporâneo: os conceitos fundamentais e a construção do novo modelo. 5. ed. São Paulo: Saraiva, 2015.

BARROSO, Luís Roberto. Controle de constitucionalidade no direito brasileiro: exposição sistemática da doutrina e análise crítica da jurisprudência.7. ed. São Paulo: Saraiva, 2016.

BINENBOJM, Gustavo. A nova jurisdição constitucional: legitimidade democrática e instrumentos de realização. 4. ed. Rio de Janeiro: Renovar, 2014.

CANOTILHO, J.J. Gomes. Direito Constitucional e Teoria da Constituição. 7. ed. Coimbra: Almedina, 2003.

CASTRIOTA, Leonardo Barci; ARAÚJO, Guilherme Maciel. Patrimônio, valores e historiografia: a preservação do conjunto habitacional do Instituto de Aposentadorias e Pensões dos Industriários - LAPI. Arquitetura Revista, vol. 5, n. 1, p. 38-54, janeiro/junho, 2009.

CASTRIOTA, Leonardo Barci. História da arquitetura e preservação do patrimônio: diálogos. Anais do Museu Histórico Nacional, vol. 43, Rio de Janeiro, 2011.

CATTONI DE OLIVEIRA, Marcelo Andrade de. Teoria discursiva da argumentação jurídica de aplicação e garantia processual jurisdicional dos direitos fundamentais. In: CATTONI DE OLIVEIRA, Marcelo Andrade. (Org.). Jurisdição e Hermenêutica Constitucional no Estado Democrático de Direito. Belo Horizonte: Mandamentos, 2004, p. 189-226.

CATTONI DE OLIVEIRA, Marcelo Andrade. Devido processo legislativo: uma justificação democrática do controle

Andrade de. Teoria discursiva da argumentação jurídica de aplicação e garantia processual jurisdicional dos direitos fundamentais. In: CATTONI DE OLIVEIRA, Marcelo Andrade. (Org.). Jurisdição e Hermenêutica Constitucional no Estado Democrático de Direito. Belo Horizonte: Mandamentos, 2004, p. 189-226. 
jurisdicional de constitucionalidade das leis e do processo legislativo. 3. ed. Belo Horizonte: Fórum, 2016a.

CATTONI DE OLIVEIRA, Marcelo Andrade de. Processo constitucional. 3. ed. Belo Horizonte: Fórum, 2016b.

COSTA GONTIJO, Pedro Augusto. Os tratados internacionais comuns e a proteção da confiança. 2018. 347 f. Dissertação (Mestrado). Programa de Pós-Graduação em Direito da Universidade Federal de Minas Gerais, Belo Horizonte, 2018.

CRUZ, Álvaro Ricardo de Souza. Jurisdição constitucional democrática. 2. ed. Belo Horizonte: Arraes Editores, 2014.

DALLARI, Pedro B. A.Constituição e tratados internacionais. São Paulo: Saraiva, 2003.

FERNANDES, Bernardo Gonçalves. Curso de Direito Constitucional. 9. ed. rev. Salvador, Juspodivm, 2017.

HÄBERLE, Peter. Hermenêutica constitucional: a sociedade aberta de intérpretes da constituição: contribuição para a interpretação pluralista e 'procedimental' da Constituição. Tradução de: Gilmar Ferreira Mendes. Porto Alegre: Sérgio Antônio Fabris, 1997.

HESSE, Konrad. A força normativa da constituição. Tradução de: Gilmar Ferreira Mendes. Porto Alegre: Sergio Antônio Fabris, 1991.

LEUZINGER, Márcia Dieguez; CUREAU, Sandra. Direito ambiental. Rio de Janeiro, Elsevier, 2008.

LUHMANN, Niklas. O direito da sociedade. São Paulo, Martins Fontes, 2016.

MENDES, Gilmar Ferreira. Argüição de Descumprimento de Preceito Fundamental ( $\$ 1^{\circ}$ do art. 102 da Constituição Federal). In: Repertório de jurisprudência, n. 04, fev., 2000, p. 113-114.

MENDES, Gilmar Ferreira. Jurisdição constitucional: o controle abstrato de normas no Brasil e na Alemanha. 5. ed. São Paulo: Saraiva, 2005.

MENDES, Gilmar Ferreira. Curso de Direito Constitucional. 8. ed. São Paulo, Saraiva, 2013.

MENDES, Gilmar Ferreira. Jurisdição constitucional: o controle abstrato de normas no Brasil e na Alemanha. 6. ed. São Paulo: Saraiva, 2014.

MEYER, Emilio Peluso Neder. A decisão no controle de constitucionalidade. São Paulo: Método, 2008.

MEYER, Emilio Peluso Neder. Decisão e jurisdição constitucional: crítica às sentenças intermediárias, técnicas e efeitos do controle de constitucionalidade em perspectiva comparada. Rio de Janeiro: Lumen Juris, 2017.

MEYER, Emilio Peluso Neder. Uma teoria dos direitos fundamentais a partir da Constituição de 1988: as principais contribuições para a construção de uma metódica brasileira. In: CLÈVE, Clemèrson Merlin; FREIRE, Alexandre (Orgs.). Direitos Fundamentais e Jurisdição Constitucional. 1ed. São Paulo: RT, 2014, v. 1, p. 361-394.

MOLINARO, Carlos Alberto; DANTAS, Fernando Antonio de Carvalho Dantas. Comentário ao artigo 216. In: CANOTILHO, José Joaquim Gomes; MENDES, Gilmar Ferreira; SARLET, Ingo Wolfgang; STRECK, Lenio Luiz. (Orgs.). Comentários à Constituição do Brasil. São Paulo: Saraiva/Almedina, 2013, p. 4270-4286.

NEVES, Marcelo. Transconstitucionalismo. São Paulo, Wmf Martins Fontes, 2009.

OTONI CARDOSO, João Pedro; COSTA GONTIJO, Pedro Augusto. Norma Jurídica e a proteção ao patrimônio material: eficácia e efetividade em tempos de relativização da cultura.In: Anais do I Congresso Mineiro de Direito do Patrimônio Cultural. Disponível em: < http://www.congressopatrimoniocultural. ufop.br/>. Acesso em 20 de setembro de 2020.

SARMENTO, Daniel. Apontamentos sobre a argüição de descumprimento de preceito fundamental. In: 
Revista de Direito Administrativo, Rio de Janeiro, n. 224, abr/jun, 2001, p. 95-116.

SARMENTO, Daniel. Ubiqüidade constitucional: os dois lados da moeda. In: SARMENTO, Daniel; SOUZA NETO, Cláudio Pereira de (Orgs.). A constitucionalizaçãao do direito: fundamentos teóricos e aplicações específicas.

Rio de Janeiro: Lumen Juris, 2007, p. 113-148.

SILVA, José Afonso da. Direito Ambiental Constitucional. 4. ed. São Paulo: Malheiros, 2003.

SILVA, José Afonso da. Curso de Direito Constitucional Positivo. 35 ed. Malheiros, São Paulo, 2012.

SILVA, Virgílio Afonso da. A constitucionalização do direito: os direitos fundamentais nas relações entre particulares. São Paulo: Malheiros Editores, 2005.

SIRVINSKAS, Luís Paulo. Manual de Direito Ambiental. 16.ed. São Paulo, Saraiva Educação, 2018.

SOUZA NETO, Cláudio Pereira de; SARMENTO, Daniel. Direito constitucional: teoria, história e métodos de trabalho. 2. ed. Belo Horizonte: Fórum, 2016.

STRECK, Lenio Luiz. Jurisdição constitucional. 5. ed. Rio de Janeiro: Forense, 2018.

TAVARES, André Ramos. Curso de direito constitucional. 10. ed. São Paulo: Saraiva, 2012.

VARELLA, Guilherme. Plano Nacional de Cultura: direitos e politicas culturais no Brasil. Rio de Janeiro: Azougue, 2014.

\section{Tábua de decisões}

BRASIL. Supremo Tribunal Federal. ADI 2. Rel. Min. Paulo Brossard. Julgamento em: 06/02/1992. DJ: 21/11/1997.

BRASIL. Supremo Tribunal Federal. ADI 939. Rel. Min. Sidney Sanches. Julgamento em: 15/12/1993. DJ: 18/03/1994.

BRASIL. Supremo Tribunal Federal. ADPF 33. Rel. Min. Gilmar Mendes. Julgamento em: 07/12/2005. DJe: $27 / 10 / 2006$.

BRASIL. Supremo Tribunal Federal.ADPF 167 MC-REF. Rel. Min. Eros Grau. Julgamento em: 01/10/2009. DJe: $26 / 02 / 2010$.

BRASIL. Supremo Tribunal Federal.ADPF 206. Rel. Min. Edson Fachin. Julgamento em: 09/03/2020. DJe: $11 / 03 / 2020$.

BRASIL. Supremo Tribunal Federal. Informativo n. 561, de 28 de setembro a 2 de outubro de 2009. Disponível em: <http://www.stf.jus.br/arquivo/informativo/documento/informativo561.htm>. Acesso em 20 de setembro de 2020 . 
Para publicar na revista Brasileira de Políticas Públicas, acesse o endereço eletrônico www.rbpp.uniceub.br

Observe as normas de publicação, para facilitar e agilizar o trabalho de edição. 